4

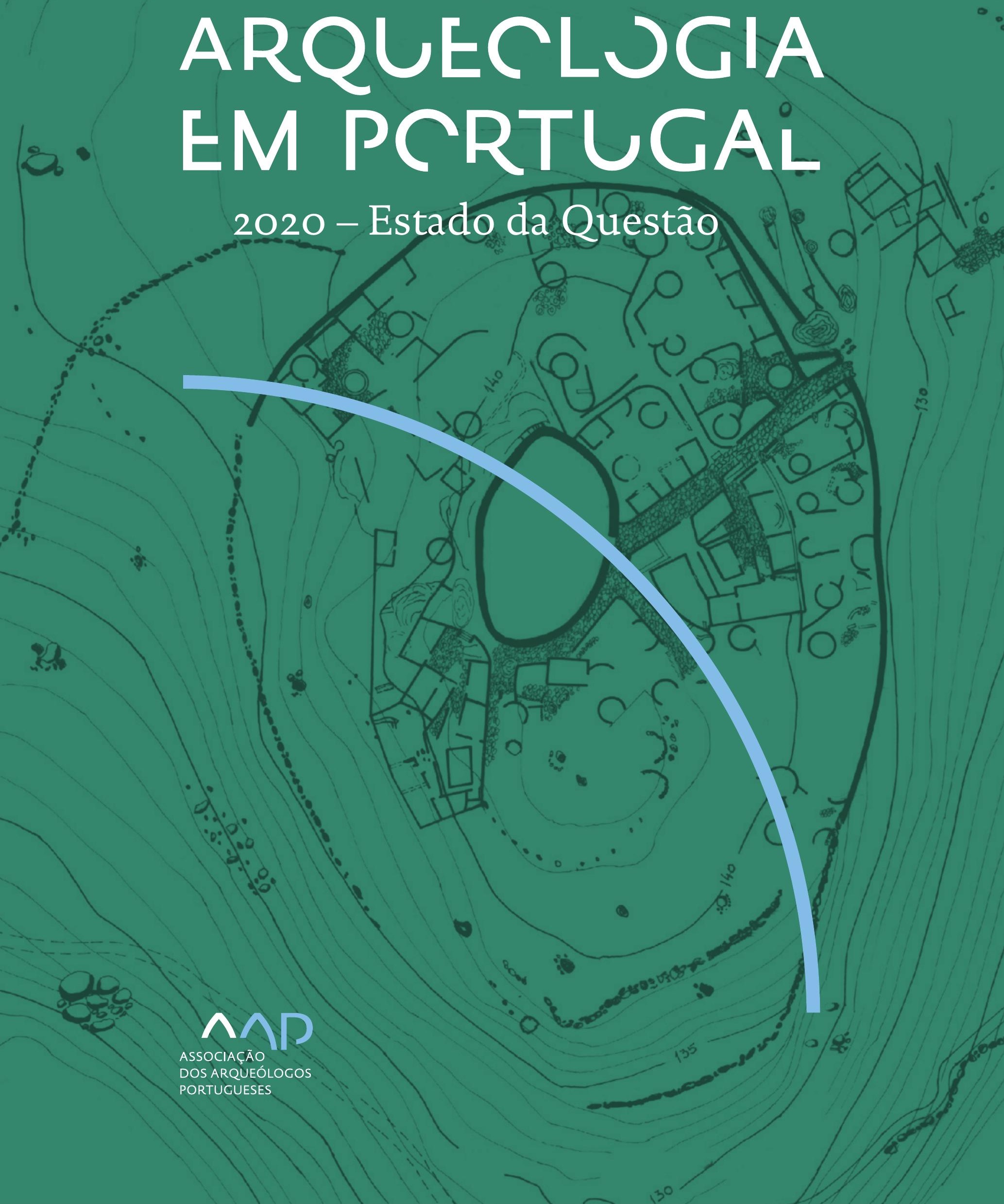


Coordenação editorial: José Morais Arnaud, César Neves e Andrea Martins Design gráfico: Flatland Design

AAP - ISBN: 978-972-9451-89-8

CITCEM - ISBN: 978-989-8970-25-1

Associação dos Arqueólogos Portugueses e CITCEM

Lisboa, 2020

O conteúdo dos artigos é da inteira responsabilidade dos autores. Sendo assim a Associação dos Arqueólogos Portugueses declina qualquer responsabilidade por eventuais equívocos ou questões de ordem ética e legal.

Desenho de capa:

Planta do castro de Monte Mozinho (Museu Municipal de Penafiel).

\section{$\hat{\wedge} \mathrm{P}$}

DOS ARQUEÓLOGOS PORTUGUESES

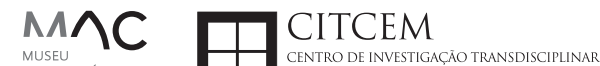
MUSEU
ARQUELLÓGICO
DO CARMO
U.PORTO

FLUP FACULDADE DE LETRAS
UNIVERSIDADE DO PORTO

Apoio

EC para a Ciência 


\section{Índice}

15 Prefácio

José Morais Arnaud

\section{Historiografia e Teoria}

17 Território, comunidade, memória e emoção: a contribuição da história da arqueologia (algumas primeiras e breves reflexões)

Ana Cristina Martins

25 Como descolonizar a arqueologia portuguesa?

Rui Gomes Coelho

41 Arqueologia e Modernidade: uma revisitação pessoal e breve de alguns aspetos da obra homónima de Julian Thomas de 2004

Vítor Oliveira Jorge

57 Dados para a História das Mulheres na Arqueologia portuguesa, dos finais do século XIX aos inícios do século XX: números, nomes e tabelas

Filipa Dimas / Mariana Diniz

73 Retractos da arqueologia portuguesa na imprensa: (in)visibilidades no feminino

Catarina Costeira / Elsa Luís

85 Arqueologia e Arqueólogos no Norte de Portugal Jacinta Bugalhão

101 Vieira Guimarães (1864-1939) e a arqueologia em Tomar: uma abordagem sobre o território e as gentes

João Amendoeira Peixoto / Ana Cristina Martins

115 Os memoráveis? A arqueologia algarvia na imprensa nacional e regional na presente centúria (2001-2019): características, visões do(s) passado(s) e a arqueologia

enquanto marca

Frederico Agosto / João Silva

129 A Evolução da Arqueologia Urbana e a Valorização Patrimonial no Barlavento Algarvio: Os casos de Portimão e Silves

Artur Mateus / Diogo Varandas / Rafael Boavida

\section{Gestão, Valorização e Salvaguarda do Património}

145 O Caderno Reivindicativo e as condições de trabalho em Arqueologia Miguel Rocha / Liliana Matias Carvalho / Regis Barbosa / Mauro Correia / Sara Simões / Jacinta Bugalhão / Sara Brito / Liliana Veríssimo Carvalho / Richard Peace / Pedro Peça / Cézer Santos

155 Os Estudos de Impacte Patrimonial como elemento para uma estratégia sustentável de minimização de impactes no âmbito de reconversões agrícolas Tiago do Pereiro

165 Salvaguarda de Património arqueológico em operações florestais: gestão e sensibilização Filipa Bragança / Gertrudes Zambujo / Sandra Lourenço / Belém Paiva / Carlos Banha / Frederico Tatá Regala / Helena Moura / Jacinta Bugalhão / João Marques / José Correia / Pedro Faria / Samuel Melro

179 Os valores do Património: uma investigação sobre os Sítios Pré-históricos de Arte Rupestre do Vale do Rio Côa e de Siega Verde José Paulo Francisco 
189 Conjugando recursos arqueológicos e naturais para potenciar as visitas ao Geoparque Litoral de Viana do Castelo (Noroeste de Portugal)

Hugo A. Sampaio / Ana M.S. Bettencourt / Susana Marinho / Ricardo Carvalhido

203 Áreas de Potencial Arqueológico na Região do Médio Tejo: Modelo Espacial Preditivo Rita Ferreira Anastácio / Ana Filipa Martins / Luiz Oosterbeek

223 Património Arqueológico e Gestão Territorial: O contributo da Arqueologia para a revisão do PDM de Avis

Ana Cristina Ribeiro

237 A coleção arqueológica do extinto Museu Municipal do Porto - Origens, Percursos e Estudos

Sónia Couto

251 Valpaços - uma nova carta arqueológica

Pedro Pereira / Maria de Fátima Casares Machado

263 Arqueologia na Cidade de Peniche

Adriano Constantino / Luís Rendeiro

273 Arqueologia Urbana: a cidade de Lagos como caso de Estudo Cátia Neto

285 Estratégias de promoção do património cultural subaquático nos Açores. O caso da ilha do Faial

José Luís Neto / José Bettencourt / Luís Borges / Pedro Parreira

297 Carta Arqueológica da Cidade Velha: Uma primeira abordagem

Jaylson Monteiro / Nireide Tavares / Sara da Veiga / Claudino Ramos / Edson Brito /

Carlos Carvalho / Francisco Moreira / Adalberto Tavares

311 Antropologia Virtual: novas metodologias para a análise morfológica e funcional Ricardo Miguel Godinho / Célia Gonçalves

\section{Didáctica da Arqueologia}

327 Como os projetos de Arqueologia podem contribuir para uma comunidade culturalmente mais consciente Alexandra Figueiredo / Claúdio Monteiro / Adolfo Silveira / Ricardo Lopes

337 Educação Patrimonial - Um cidadão esclarecido é um cidadão ativo! Ana Paula Almeida

351 A aproximação da Arqueologia à sala de aula: um caso de estudo no $3^{\circ}$ ciclo do Ensino Básico Luís Serrão Gil

363 Arqueologia 3.o - Pensar e comunicar a Arqueologia para um futuro sustentável Mónica Rolo

377 “Conversa de Arqueólogos" - Divulgar a Arqueologia em tempos de Pandemia Diogo Teixeira Dias

389 Escola Profissional de Arqueologia: desafios e oportunidades Susana Nunes / Dulcineia Pinto / Júlia Silva / Ana Mascarenhas

399 Os Museus de Arqueologia e os Jovens: a oferta educativa para o público adolescente Beatriz Correia Barata / Leonor Medeiros

411 O museu universitário como mediador entre a ciência e a sociedade: o exemplo da secção de arqueologia no Museu de História Natural e da Ciência da Universidade do Porto (MHNC-UP)

Rita Gaspar 
421 Museu de Lanifícios: Real Fábrica de Panos. Atividades no âmbito da Arqueologia Beatriz Correia Barata / Rita Salvado

427 Arqueologia Pública e o caso da localidade da Mata (Torres Novas) Cláudia Manso / Ana Rita Ferreira / Cristiana Ferreira / Vanessa Cardoso Antunes

431 Do sítio arqueológico ao museu: um percurso (também) didático Lídia Fernandes

447 Estão todos convidados para a Festa! E para dançar também... O projecto do Serviço Educativo do Museu Arqueológico do Carmo na $5^{\underline{a}}$ Edição da Festa da Arqueologia Rita Pires dos Santos

459 O “Clã de Carenque”, um projeto didático de arqueologia Eduardo Gonzalez Rocha

469 Mediação cultural: peixe que puxa carroça nas Ruínas Romanas de Troia Inês Vaz Pinto / Ana Patrícia Magalhães / Patrícia Brum / Filipa Santos

481 Didática Arqueológica, experiências do Projeto Mértola Vila Museu Maria de Fátima Palma / Clara Rodrigues / Susana Gómez / Lígia Rafael

\section{Arte Rupestre}

497 Os inventários de arte rupestre em Portugal Mila Simões de Abreu

513 O projeto FIRST-ART - conservação, documentação e gestão das primeiras manifestações de arte rupestre no Sudoeste da Península Ibérica: as grutas do Escoural e Maltravieso Sara Garcês / Hipólito Collado / José Julio García Arranz / Luiz Oosterbeek / António Carlos Silva / Pierluigi Rosina / Hugo Gomes / Anabela Borralheiro Pereira / George Nash / Esmeralda Gomes / Nelson Almeida / Carlos Carpetudo

523 Trabalhos de documentação de arte paleolítica realizados no âmbito do projeto PalæoCôa André Tomás Santos / António Fernando Barbosa / Luís Luís / Marcelo Silvestre / Thierry Aubry

537 Imagens fantasmagóricas, silhuetas elusivas: as figuras humanas na arte do Paleolítico Superior da região do Côa Mário Reis

$55^{1}$ Os motivos zoomórficos representados nas placas de tear de Vila Nova de São Pedro (Azambuja, Portugal) Andrea Martins / César Neves / José M. Arnaud / Mariana Diniz

571 Arte Rupestre do Monte de Góios (Lanhelas, Caminha). Síntese dos resultados dos trabalhos efectuados em 2007-2009 Mário Varela Gomes

599 Gravuras rupestres de barquiformes no Monte de S. Romão, Guimarães, Noroeste de Portugal Daniela Cardoso

613 Círculos segmentados gravados na Bacia do Rio Lima (Noroeste de Portugal): contributos para o seu estudo Diogo Marinho / Ana M.S. Bettencourt / Hugo Aluai Sampaio

631 Equídeos gravados no curso inferior do Rio Mouro, Monção (NW Portugal). Análise preliminar Coutinho, L.M. / Bettencourt, A.M.S / Sampaio, Hugo A.S

645 Paletas na Arte Rupestre do Noroeste de Portugal. Inventário preliminar Bruna Sousa Afonso / Ana M. S. Bettencourt / Hugo A. Sampaio 


\section{Pré-História}

661 O projeto Miño/Minho: balanço de quatro anos de trabalhos arqueológicos Sérgio Monteiro-Rodrigues / João Pedro Cunha-Ribeiro / Eduardo Méndez-Quintas / Carlos Ferreira / Pedro Xavier / José Meireles / Alberto Gomes / Manuel Santonja / Alfredo Pérez-González

677 A ocupação paleolítica da margem esquerda do Baixo Minho: a indústria lítica do sítio de Pedreiras 2 (Monção, Portugal) e a sua integração no contexto regional Carlos Ferreira / João Pedro Cunha-Ribeiro / Sérgio Monteiro-Rodrigues / Eduardo Méndez-Quintas / Pedro Xavier / José Meireles / Alberto Gomes / Manuel Santonja / Alfredo Pérez-González

693 O sítio acheulense do Plistocénico médio da Gruta da Aroeira Joan Daura / Montserrat Sanz / Filipa Rodrigues / Pedro Souto / João Zilhão

703 As sociedades neandertais no Barlavento algarvio: modelos preditivos com recurso aos SIG

Daniela Maio

715 A utilização de quartzo durante o Paleolítico Superior no território dos vales dos rios Vouga e Côa

Cristina Gameiro / Thierry Aubry / Bárbara Costa / Sérgio Gomes / Luís Luís / Carmen Manzano / André Tomás Santos

733 Uma perspetiva diacrónica da ocupação do concheiro do Cabeço da Amoreira (Muge, Portugal) a partir da tecnologia lítica Joana Belmiro / João Cascalheira / Célia Gonçalves

745 Novos dados sobre a Pré-história Antiga no concelho de Palmela. A intervenção arqueológica no sítio do Poceirão I

Michelle Teixeira Santos

757 Problemas em torno de Datas Absolutas Pré-Históricas no Norte do Alentejo Jorge de Oliveira

771 Povoamento pré-histórico nas áreas montanhosas do NO de Portugal: o Abrigo 1 de Vale de Cerdeira Pedro Xavier / José Meireles / Carlos Alves

783 Apreciação do povoamento do Neolítico Inicial na Baixa Bacia do Douro. A Lavra I (Serra da Aboboreira) como caso de estudo Maria de Jesus Sanches

797 O Processo de Neolitização na Plataforma do Mondego: os dados do Sector C do Outeiro dos Castelos de Beijós (Carregal do Sal)

João Carlos de Senna-Martinez / José Manuel Quintã Ventura / Andreia Carvalho / Cíntia Maurício

823 Novos trabalhos na Lapa da Bugalheira (Almonda, Torres Novas) Filipa Rodrigues / Pedro Souto / Artur Ferreira / Alexandre Varanda / Luís Gomes / Helena Gomes / João Zilhão

837 A pedra polida e afeiçoada do sítio do Neolítico médio da Moita do Ourives (Benavente, Portugal)

César Neves

857 Casal do Outeiro (Encarnação, Mafra): novos contributos para o conhecimento do povoamento do Neolítico final na Península de Lisboa.

Cátia Delicado / Carlos Maneira e Costa / Marta Miranda / Ana Catarina Sousa

873 Stresse infantil, morbilidade e mortalidade no sítio arqueológico do Neolítico Final/ Calcolítico ( $4^{\circ}$ e $3^{\circ}$ milénio a.C.) do Monte do Carrascal 2 (Ferreira do Alentejo, Beja) Liliana Matias de Carvalho / Sofia N. Wasterlain 
885 Come together: O Conjunto Megalítico das Motas (Monção, Viana do Castelo) e as expressões Campaniformes do Alto Minho Ana Catarina Basílio / Rui Ramos

899 Trabalhos arqueológicos no sítio Calcolítico da Pedreira do Poio Carla Magalhães / João Muralha / Mário Reis / António Batarda Fernandes

913 O sítio arqueológico de Castanheiro do Vento. Da arquitectura do sítio à arquitectura de um território João Muralha Cardoso

925 Estudo zooarqueológico das faunas do Calcolítico final de Vila Nova de São Pedro (Azambuja, Portugal): Campanhas de 2017 e 2018 Cleia Detry / Ana Catarina Francisco / Mariana Diniz / Andrea Martins / César Neves / José Morais Arnaud

943 As faunas depositadas no Museu Arqueológico do Carmo provenientes de Vila Nova de São Pedro (Azambuja): as campanhas de 1937 a 1967 Ana Catarina Francisco / Cleia Detry / César Neves / Andrea Martins / Mariana Diniz / José Morais Arnaud

959 Análise funcional de material lítico em sílex do castro de Vila Nova de S. Pedro (Azambuja, Portugal): uma primeira abordagem Rafael Lima

971 O recinto da Folha do Ouro 1 (Serpa) no contexto dos recintos de fossos calcolíticos alentejanos

António Carlos Valera / Tiago do Pereiro / Pedro Valério / António M. Monge Soares

\section{Proto-História}

987 Produção de sal marinho na Idade do Bronze do noroeste Português. Alguns dados para uma reflexão

Ana M. S. Bettencourt / Sara Luz / Nuno Oliveira / Pedro P. Simões / Maria Isabel C. Alves / Emílio Abad-Vidal

1001 A estátua-menir do Pedrão ou de São Bartolomeu do Mar (Esposende, noroeste de Portugal) no contexto arqueológico da fachada costeira de entre os rios Neiva e Cávado Ana M. S. Bettencourt / Manuel Santos-Estévez / Pedro Pimenta Simões / Luís Gonçalves

1015 O Castro do Muro (Vandoma/Baltar, Paredes) - notas para uma biografia de ocupação da Idade do Bronze à Idade Média

Maria Antónia D. Silva / Ana M. S. Bettencourt / António Manuel S. P. Silva / Natália Félix

1031 Do Bronze Final à Idade Média - continuidades e hiatos na ocupação de Povoados em Oliveira de Azeméis João Tiago Tavares / Adriaan de Man

1041 As faunas do final da Idade do Bronze no Sul de Portugal: leituras desde o Outeiro do Circo (Beja)

Nelson J. Almeida / Íris Dias / Cleia Detry / Eduardo Porfírio / Miguel Serra

1055 A Espada do Monte das Oliveiras (Serpa) - uma arma do Bronze Pleno do Sudoeste Rui M. G. Monge Soares / Pedro Valério / Mariana Nabais / António M. Monge Soares

1065 São Julião da Branca (Albergaria-a-Velha) - Investigação e valorização de um povoado do Bronze Final

António Manuel S. P. Silva / Paulo A. P. Lemos / Sara Almeida e Silva / Edite Martins de Sá

1083 Do castro de S. João ao Mosteiro de Santa Clara: notícia de uma intervenção arqueológica, em Vila do Conde Rui Pinheiro 
1095 O castro de Ovil (Espinho), um quarto de século de investigação - resultados e questões em aberto

Jorge Fernando Salvador / António Manuel S. P. Silva

1111 O Castro de Salreu (Estarreja), um povoado proto-histórico no litoral do Entre Douro e Vouga

Sara Almeida e Silva / António Manuel S. P. Silva / Paulo A. P. Lemos / Edite Martins de Sá

1127 Castro de Nossa Senhora das Necessidades (Sernancelhe): uma primeira análise artefactual Telma Susana O. Ribeiro

${ }_{1141}$ A cividade de Bagunte. O estado atual da investigação Pedro Brochado de Almeida

1153 Zoomorfos na cerâmica da Idade do Ferro no NW Peninsular: inventário, cronologias e significado Nuno Oliveira / Cristina Seoane

1163 Vasos gregos em Portugal: diferentes maneiras de contar a história do intercâmbio cultural na Idade do Ferro

Daniela Ferreira

1175 Os exotica da necrópole da Idade do Ferro do Olival do Senhor dos Mártires (Alcácer do Sal) no seu contexto regional

Francisco B. Gomes

\section{Antiguidade Clássica e Tardia}

1191 O uso de madeira como combustível no sítio da Quinta de Crestelos (Baixo Sabor): da Idade do Ferro à Romanização Filipe Vaz / João Tereso / Sérgio Simões Pereira / José Sastre / Javier Larrazabal Galarza / Susana Cosme / José António Pereira / Israel Espi

1207 Cultivos de Época Romana no Baixo Sabor: continuidade em tempos de mudança? João Pedro Tereso / Sérgio Simões Pereira / Filipe Santos / Luís Seabra / Filipe Vaz

1221 A casa romana na Hispânia: aplicação dos modelos itálicos nas províncias ibéricas Fernanda Magalhães / Diego Machado / Manuela Martins

1235 As pinturas murais romanas da Rua General Sousa Machado, n. ${ }^{5}$ 1, Chaves José Carvalho

1243 Trás do Castelo (Vale de Mir, Pegarinhos, Alijó) - Uma exploração agrícola romana do Douro

Tony Silvino / Pedro Pereira

1255 A sequência de ocupação no quadrante sudeste de Bracara Augusta: as transformações de uma unidade doméstica Lara Fernandes / Manuela Martins

1263 Os Mosaicos com decoração geométrica e geométrico-vegetalista dos sítios arqueológicos da área do Conuentus Bracaraugustanus. Novas abordagens quanto à conservação, restauro, decoração e datação Maria de Fátima Abraços / Licínia Wrench

1277 “Casa Romana” do Castro de São Domingos (Cristelos, Lousada): Escavação, Estudo e Musealização Paulo André de P. Lemos

1291 A arqueobotânica no Castro de Guifões (Matosinhos, Noroeste de Portugal): O primeiro estudo carpológico

Luís Seabra / Andreia Arezes / Catarina Magalhães / José Varela / João Pedro Tereso 
1305 Um Horreum Augustano na Foz do Douro (Monte do Castelo de Gaia, Vila Nova de Gaia) Rui Ramos

1311 Ponderais romanos na Lusitânia: padrões, formas, materiais e contextos de utilização Diego Barrios Rodríguez

1323 Um almofariz centro-itálico na foz do Mondego

Marco Penajoia

1335 Estruturas romanas de Carnide - Lisboa Luísa Batalha / Mário Monteiro / Guilherme Cardoso

1347 O contexto funerário do sector da "necrópole NO" da Rua das Portas de S. Antão (Lisboa): o espaço, os artefactos, os indivíduos e a sua interconectividade na interpretação do passado Sílvia Loja, José Carlos Quaresma, Nelson Cabaço, Marina Lourenço, Sílvia Casimiro, Rodrigo Banha da Silva, Francisca Alves-Cardoso

${ }_{1361}$ Povoamento em época Romana na Amadora - resultados de um projeto pluridisciplinar Gisela Encarnação / Vanessa Dias

1371 A Arquitectura Residencial em Mirobriga (Santiago do Cacém): contributo a partir de um estudo de caso Filipe Sousa / Catarina Felício

${ }_{1385}$ O fim do ciclo. Saneamento e gestão de resíduos nos edifícios termais de Mirobriga (Santiago do Cacém)

Catarina Felício / Filipe Sousa

1399 Balsa, Topografia e Urbanismo de uma Cidade Portuária Vítor Silva Dias / João Pedro Bernardes / Celso Candeias / Cristina Tété Garcia

1413 No Largo das Mouras Velhas em Faro (2017): novas evidências da necrópole norte de Ossonoba e da sua ocupação medieval Ricardo Costeira da Silva / Paulo Botelho / Fernando Santos / Liliana Nunes

1429 Instrumentos de pesca recuperados numa fábrica de salga em Ossonoba (Faro) Inês Rasteiro / Ricardo Costeira da Silva / Paulo Botelho

1439 A Necrópole Romana do Eirô, Duas Igrejas (Penafiel): intervenção arqueológica de 2016 Laura Sousa / Teresa Soeiro

1457 Ritual, descarte ou afetividade? A presença de Canis lupus familiaris na Necrópole Noroeste de Olisipo (Lisboa)

Beatriz Calapez Santos / Sofia Simões Pereira / Rodrigo Banha da Silva / Sílvia Casimiro / Cleia Detry / Francisca Alves Cardoso

1467 Dinâmicas económicas em Bracara na Antiguidade Tardia Diego Machado / Manuela Martins / Fernanda Magalhães / Natália Botica

1479 Cerâmicas e Vidros da Antiguidade Tardia do Edifício sob a Igreja do Bom Jesus (Vila Nova de Gaia) Joaquim Filipe Ramos

1493 Novos contributos para a topografia histórica de Mértola no período romano e na Antiguidade Tardia Virgílio Lopes

\section{8. Época Medieval}

1511 Cerâmicas islâmicas no Garb setentrional "português": algumas evidências e incógnitas Constança dos Santos / Helena Catarino / Susana Gómez / Maria José Gonçalves / Isabel Inácio / Gonçalo Lopes / Jacinta Bugalhão / Sandra Cavaco / Jaquelina Covaneiro / Isabel Cristina Fernandes / Ana Sofia Gomes 
1525 Contributo para o conhecimento da cosmética islâmica, em Silves, durante a Idade Média Rosa Varela Gomes

1537 Yábura e o seu território - uma análise histórico-arqueológica de Évora entre os séculos VIII-XII José Rui Santos

1547 A encosta sul do Castelo de Palmela - resultados preliminares da escavação arqueológica Luís Filipe Pereira / Michelle Teixeira Santos

1559 A igreja de São Lourenço (Mouraria, Lisboa): um conjunto de silos e de cerâmica medieval islâmica

Andreia Filipa Moreira Rodrigues

1571 O registo material de movimentações populacionais no Médio Tejo, durante os séculos XII-XIII. Dois casos de "sunken featured buildings", nos concelhos de Cartaxo e Torres Novas Marco Liberato / Helena Santos / Nuno Santos

1585 O nordeste transmontano nos alvores da Idade média. Notas para reflexão Ana Maria da Costa Oliveira

1601 Sepulturas escavadas na rocha do Norte de Portugal e do Vale do Douro: primeiros resultados do Projecto SER-NPVD

Mário Jorge Barroca / César Guedes / Andreia Arezes / Ana Maria Oliveira

1619 "Portucalem Castrum Novum" entre o Mediterrâneo e o Atlântico: o estudo dos materiais cerâmicos alto-medievais do arqueossítio da rua de D. Hugo, nํ. 5 (Porto) João Luís Veloso

1627 A Alta Idade Média na fronteira de Lafões: notas preliminares sobre a Arqueologia no Concelho de Vouzela

Manuel Luís Real / Catarina Tente

1641 Um conjunto cerâmico medieval fora de portas: um breve testemunho aveirense Susana Temudo

${ }_{1651}$ Os Lóios do Porto: uma perspetiva integrada no panorama funerário da Baixa Idade Média à Época Moderna em meios urbanos em Portugal

Ana Lema Seabra

1659 O Caminho Português Interior de Santiago como eixo viário na Idade Média Pedro Azevedo

1665 Morfologia Urbana: Um exercício em torno do Castelo de Ourém André Donas-Botto / Jaqueline Pereira

1677 Intervenção arqueológica na Rua Marquês de Pombal/Largo do Espírito Santo (Bucelas, Loures)

Florbela Estêvão / Nathalie Antunes-Ferreira / Dário Ramos Neves / Inês Lisboa

1691 O Cemitério Medieval do Poço do Borratém e a espacialidade funerária na cidade de Lisboa Inês Belém / Vanessa Filipe / Vasco Noronha Vieira / Sónia Ferro / Rodrigo Banha da Silva

1705 Um Espaço Funerário Conventual do séc. XV em Lisboa: o caso do Convento de São Domingos da Cidade Sérgio Pedroso / Sílvia Casimiro / Rodrigo Banha da Silva / Francisca Alves Cardoso

\section{9. Época Moderna e Contemporânea}

1721 Arqueologia Moderna em Portugal: algumas reflexões críticas em torno da quantificação de conjuntos cerâmicos e suas inferências históricas e antropológicas Rodrigo Banha da Silva / André Bargão / Sara da Cruz Ferreira

1733 Faianças de dois contextos entre os finais do século XVI e XVIII do Palácio dos Condes de Penafiel, Lisboa

Martim Lopes / Tomás Mesquita 
1747 Um perfil de consumo do século XVIII na foz do Tejo: O caso do Mercado da Ribeira, Lisboa Sara da Cruz Ferreira / Rodrigo Banha da Silva / André Bargão

1761 Os Cachimbos dos Séculos XVII e XVIII do Palácio Mesquitela e Convento dos Inglesinhos (Lisboa)

Inês Simão / Marina Pinto / João Pimenta / Sara da Cruz Ferreira / André Bargão / Rodrigo Banha da Silva

1775 "Tomar os fumos da erua que chamão em Portugal erua sancta». Estudo de Cachimbos provenientes da Rua do Terreiro do Trigo, Lisboa

Miguel Martins de Sousa / José Pedro Henriques / Vanessa Galiza Filipe

1787 Cachimbos de Barro Caulínitico da Sé da Cidade Velha (República de Cabo Verde)

Rodrigo Banha da Silva / João Pimenta / Clementino Amaro

1801 Algumas considerações sobre espólio não cerâmico recuperado no Largo de Jesus (Lisboa) Carlos Boavida

1815 Adereços de vidro, dos séculos XVI-XVIII, procedentes do antigo Convento de Santana de Lisboa (anéis, braceletes e contas)

Joana Gonçalves / Rosa Varela Gomes / Mário Varela Gomes

1837 Da ostentação, luxo e poder à simplicidade do uso quotidiano: arqueologia e simbologia de joias e adornos da Idade Moderna Portuguesa Jéssica Iglésias

1849 Os amuletos em Portugal - dos objetos às superstições: o coral vermelho Alexandra Vieira

1865 Cerâmicas de Vila Franca de Xira nos séculos XV e XVI Eva Pires

1879 «Não passa por teu o que me pertence». Marcas de individualização associadas a faianças do Convento de Nossa Senhora de Aracoeli, Alcácer do Sal Catarina Parreira / Íris Fragoso / Miguel Martins de Sousa

1891 Cerâmica de Leiria: alguns focos de produção

Jaqueline Pereira / André Donas-Botto

1901 Os Fornos na Rua da Biquinha, em Óbidos Hugo Silva / Filipe Oliveira

1909 A casa de Pêro Fernandes, contador dos contos de D. Manuel I: o sítio arqueológico da Silha do Alferes, Seixal (século XVI) Mariana Nunes Ferreira

1921 O Alto da Vigia (Sintra) e a vigilância e defesa da costa Alexandre Gonçalves / Sandra Santos

1937 O contexto da torre sineira da Igreja de Santa Maria de Loures Paulo Calaveira / Martim Lopes

1949 A Necrópole do Hospital Militar do Castelo de São Jorge e as práticas funerárias na Lisboa de Época Moderna Susana Henriques / Liliana Matias de Carvalho / Ana Amarante / Sofia N. Wasterlain

1963 SAND - Sarilhos Grandes Entre dois Mundos: o adro da Igreja e a Paleobiologia dos ossos humanos recuperados

Paula Alves Pereira / Roger Lee Jesus / Bruno M. Magalhães

1975 Expansão urbana da vila de Cascais no século XVII e XVIII: a intervenção arqueológica na Rua da Vitória no 15 a 17

Tiago Pereira / Vanessa Filipe

1987 Novos dados para o conhecimento do Urbanismo de Faro em época Moderna Ana Rosa 
1995 Um exemplo de Arqueologia Urbana em Alcoutim: o Antigo Edifício dos CTT Marco Fernandes / Marta Dias / Alexandra Gradim / Virgílio Lopes / Susana Gómez Martínez

2007 Palácio dos Ferrazes (Rua das Flores/Rua da Vitória, Porto): a cocheira de Domingos Oliveira Maia

Francisco Raimundo

2021 As muitas vidas de um edifício urbano: História, Arqueologia e Antropologia no antigo Recreatório Paroquial de Penafiel Helena Bernardo / Jorge Sampaio / Marta Borges

2035 O convento de Nossa Senhora da Esperança de Ponta Delgada: o contributo da arqueologia para o conhecimento de um monumento identitário João Gonçalves Araújo / N’Zinga Oliveira

2047 Arqueologia na ilha do Corvo... em busca da capela de Nossa Senhora do Rosário Tânia Manuel Casimiro / José Luís Neto / Luís Borges / Pedro Parreira

2059 Perdidos à vista da Costa. Trabalhos arqueológicos subaquáticos na Barra do Tejo Jorge Freire / José Bettencourt / Augusto Salgado

2071 Arqueologia marítima em Cabo Verde: enquadramento e primeiros resultados do projecto CONCHA

José Bettencourt / Adilson Dias / Carlos Lima / Christelle Chouzenoux / Cristóvão Fonseca / Dúnia Pereira / Gonçalo Lopes / Inês Coelho / Jaylson Monteiro / José Lima / Maria Eugénia Alves / Patrícia Carvalho / Tiago Silva

2085 Trabalhos arqueológicos na Cidade Velha (Ribeira Grande de Santiago, Cabo Verde): reflexões sobre um projecto de investigação e divulgação patrimonial André Teixeira / Jaylson Monteiro / Mariana Mateus / Nireide Tavares / Cristovão Fonseca / Gonçalo C. Lopes / Joana Bento Torres / Dúnia Pereira / André Bargão / Aurélie Mayer / Bruno Zélie / Carlos Lima / Christelle Chouzenoux / Inês Henriques / Inês Pinto Coelho / José Lima / Patrícia Carvalho / Tiago Silva

2103 A antiga fortificação de Quelba / Khor Kalba (E.A.U.). Resultados de quatro campanhas de escavações, problemáticas e perspectivas futuras Rui Carita / Rosa Varela Gomes / Mário Varela Gomes / Kamyar Kamyad

2123 Colónias para homens novos: arqueologia da colonização agrária fascista no noroeste ibérico Xurxo Ayán Vila / José Mạ . Señorán Martín 


\title{
PALETAS NA ARTE RUPESTRE DO NOROESTE DE PORTUGAL. INVENTÁRIO PRELIMINAR
}

\author{
Bruna Sousa Afonso ${ }^{1}$, Ana M. S. Bettencourt ${ }^{2}$, Hugo A. Sampaio ${ }^{2,3}$
}

\begin{abstract}
RESUMO
As paletas são pouco frequentes na arte rupestre do Noroeste de Portugal. Encontram-se tanto em contextos de Arte Atlântica Clássica, como de Arte Esquemática de ar livre, mas também noutros contextos com motivos de difícil classificação. Apesar de conhecidos não existe um inventário de sítios com este motivo nem um quadro tipológico dos mesmos, apesar de alguma subdivisão realizada por Bettencourt (2017a). Também não são conhecidos os contextos culturais e físicos em que se encontram.

O objetivo deste trabalho é o de colmatar estas ausências através de um primeiro inventário, da criação de uma tipologia de motivos e de uma tentativa de inserção espacial e cultural dos mesmos.

Palavras-chave: Noroeste de Portugal, Gravuras rupestres, Paletas, Tipologia e espacialidade.
\end{abstract}

\begin{abstract}
Palettes are rare in the rock art of Northwest Portugal. They are found both in Classical Atlantic Art and openair Schematic Art contexts, but also in other contexts of difficult classifications. Although known, there is no inventory of sites with this motif or a typological table of them, despite some subdivision made by Bettencourt (2017a). The cultural and physical contexts, in which they are found, are also not known.

The aim of this work is to rectify these absences through a first inventory, the creation of a typology of motifs and an attempt at their spatial and cultural integration.

Keywords: Northwest of Portugal, Rock engravings, Palettes, Typology and spatiality.
\end{abstract}

\section{INTRODUÇÃO}

O motivo designado por "paleta", apesar de raramente gravado, encontra-se em contextos de Arte Atlântica Clássica, de Arte Esquemática de ar livre e noutros de difícil classificação.

As paletas ocorrem no Noroeste da Península Ibérica, especialmente na Galiza e no Norte de Portugal, embora também sejam conhecidos no Norte de Itália (Fossati, 2007).

Quanto à definição morfológica daquilo que é uma paleta, Peña Santos e Vázquez Varela (1979, p. 97), afirmam que “(...) obedecem a un mismo tipo, es- tando rematado su apéndice inferior por un ensanchamiento circular que puede ser macizo o hueco a modo de anillo". Costas Goberna e Novoa Alvaréz (1993, p. 199) consideram que correspondem "una figura definida por rebaje de planta rectangular o cuadrada que presenta en un extremo en el centro un surco a modo de mango acabado com más o menos detalle". Fossati (2007, p. 135), para os Alpes italianos, define as paletas como a representação de um objeto "quadrangular (rarely circular) engraving with a handle (often also with a pommel)". Abreu (2012) chama-lhes "shovel-like shape". Recentemente, Bettencourt (2017a, p. 1058), defende

\footnotetext{
1. Aluna de Mestrado em Arqueologia da Universidade do Minho; bruna-ooo5@live.com.pt

2. Laboratório de Paisagens, Património e Território (Lab2PT); Departamento de História da Universidade do Minho, Braga, Portugal; anabett@uaum.uminho.pt

3. Escola de Hotelaria e Turismo do Instituto Politécnico do Cávado e do Ave (ESHT/IPCA); Centro de Investigação, Desenvolvimento e Inovação em Turismo (CITur); hugoaluai@gmail.com
} 
uma conceção alargada da paleta considerando que pode incluir qualquer objeto com a parte superior de forma circular, oval, quadrangular ou retangular, e a parte inferior com uma espécie de "cabo" ou "pega". Este "cabo" pode ser perpendicular ou curvo, dando continuação ao corpo do objeto e podendo, em certos casos, terminar de forma pontiaguda, horizontal, circular ou irregular. Será esta a conceção usada neste trabalho.

Relativamente às propostas cronológicas, Peña Santos e Vázquez Varela (1979) atribuem as paletas ao Bronze Final. Baptista (1984, p. 76) também integra a sua origem no Bronze Final embora considere que persistem para a Idade do Ferro enquanto Santos-Estévez (2007, p. 52) propõe uma cronologia desde o Bronze Final até à Idade Média, considerando que o seu apogeu ocorre na Idade do Ferro. Para Valcamónica, nos Alpes italianos, Fossati (2007), atribui-as à $3^{\underline{a}}$ fase cronológica do sítio que corresponde à Idade do Bronze Final (final do $2^{\circ}$ milénio a.C.), por se sobreporem a espirais e punhais, motivos habitualmente inseridos no Neolítico ou Calcolítico. Admite que persistam para a Idade do Ferro, período que se manifesta na $4^{\underline{a}}$ fase (finais do séc. VI a.C.). Bettencourt e Rodrigues (2013) consideram-nas da Idade do Ferro, a propósito do estudo do Fieiral 2, em Melgaço. Posteriormente, Bettencourt (2017a; 2017b) insere as paletas de pá quadrangular, oval ou semi-oval, na Idade do Bronze Final, usando para tal o paralelo que se pode estabelecer com algumas tipologias de navalhas de barbear desta cronologia. Esta autora considera, ainda, as paletas de pá circular, da mesma cronologia, por similitude aos espelhos representados nas estelas do Sudoeste Ibérico. Em relação às suas interpretações, Ferri (1975) coloca a hipótese de que podem ser espelhos, opinião refutada por Marinis (1975) que defende que estes objetos não podiam corresponder a espelhos porque o ferro não é um material refletor. Fossati (2007, p. 135) sugere que as paletas são a representação de um símbolo de "admissão" feminina porque ocorrem depósitos de paletas em bronze (e mais tarde em ferro), em sepulturas femininas do Bronze Final, como nas culturas Golasecca (Bronze Final e Ferro Inicial), Villanova (Idade do Ferro Inicial) e Venética, (em 1000 a.C.). Defende, ainda, que em Valcamónica, estão localizadas espacialmente no que se poderá interpretar como a "entrada" da rocha, simbolizando, desta forma, uma restrição, como é o caso das rochas 35 e 5o, em Naquane, e da rocha
4, em In Valle. Na Idade do Ferro, verifica que estão associadas a guerreiros. A propósito de uma paleta encontrada, entre outros objetos para manejar com o fogo (como espetos e colheres tipo concha), no túmulo feminino de Nerca Tomb, em Este, Pádua, Fossati (2007, p. 135) sugere que estes objetos poderiam servir para remover cinzas ou retirar o pão do fogo, simbolizando assim o fogo ou algo relacionado com ele, servindo, apenas, para propósitos rituais. Já Abreu (2012, p. 525) sugere que este motivo poderá corresponder a pás de trabalho, em madeira, a pequenos objetos ritualistas para recolher cinzas dos mortos, a espelhos de bronze ou a um misto de todas estas funções.

Apesar destes trabalhos, o estudo destes motivos gravados, em Portugal, é ainda incipiente. Não há inventários, nem se conhece a sua distribuição geográfica e o seu contexto físico e cultural; não há estudos tipológicos sistemáticos que individualizem os diferentes grupos designados pelo mesmo nome; não há estudos que relacionem cada grupo tipológico com outros motivos gravados no mesmo afloramento e não há estudos espaciais que relacionem estes motivos com outros contextos arqueológicos mais próximos que possibilitem novas hipóteses cronológicas e interpretativas. Considerando o que foi dito, pretende-se, com este trabalho, contribuir para o inventário deste tipo de motivos, para a individualização morfológica dos diferentes motivos designados por paletas e para o estudo da localização geográfica e espacial de cada um dos tipos identificados, na ampla escala de análise. Através deste trabalho, pretende-se, ainda, identificar eventuais padrões geográficos para cada tipo estabelecido. O espaço de trabalho, será o Noroeste de Portugal, com limite oriental na sub-bacia do rio Tâmega.

\section{METODOLOGIA}

A metodologia usada na elaboração deste trabalho compreendeu pesquisa bibliográfica e em portais, como o Corpus Virtual de Arte Rupestre do Noroeste Português - CVARN (www.cvarn.org). Foi também consultada cartografia, como as Cartas Militares de Portugal, na escala 1: 2500o, de Chaves, Fafe, Mondim de Basto, Ponte da Barca e Viana do Castelo. Não houve oportunidade de efetuar qualquer saída de campo. Após a recolha de dados, estes foram tratados num Sistema de Informação Geográfica, com vista a uma melhor análise da distribuição 
geográfica das paletas e das relações dos afloramentos em que se encontram, com o território.

\section{INVENTÁRIO}

O inventário está organizado por ordem alfabética dos distritos. No âmbito de cada distrito também está organizado pela ordem alfabética dos concelhos e das freguesias.

Os descritores de análise são: 1) a localização administrativa; 2) o contexto físico e ambiental; 3) o contexto arqueológico; 4) a caraterização do afloramento gravado; 5) a descrição dos motivos gravados e 6) a biografia do afloramento.

\subsection{Distrito de Braga}

\subsubsection{Concelho de Fafe}

\section{Cabanas}

Localização administrativa: Lugar: Lameira; Freguesia: São Gens.

Contexto físico e ambiental: localiza-se no topo do planalto da Lameira, a $679 \mathrm{~m}$ de altitude.

Caraterização do afloramento gravado: afloramento de granito, pouco destacado do solo, com a face superior horizontalizada.

Descrição dos motivos gravados: Cabanas foi publicada por Sampaio e Garcia Diez (2000) que não identificaram as paletas. Estas foram identificadas por Cardoso (2015, p. 85) que aí individualiza 4 destes motivos ao identificar três fases de gravação neste sítio, sendo a primeira composta por círculos, círculos com covinha central e covinhas; a segunda, por paletas, que data da proto-história e a terceira correspondente a um momento de cristianização onde inscreve as cruzes latinas que se terão adossado a alguns círculos. Esta autora, observa ainda, que os sulcos correspondem a destruições de época mais recente. Quanto às paletas, 3 são de pá sub-retangular e 1 de pá trapezoidal. Três delas encontram-se na periferia do afloramento e uma no seu centro. Orientam-se para várias direções. Duas estão sobrepostas por covinhas e por um motivo em baixo relevo. As paletas foram gravadas em baixo relevo (Figura 1). Bibliografia: Sampaio e Garcia Diez, 200o; Cardoso, 2015 .

\subsection{Distrito de Viana do Castelo}

\subsubsection{Concelho de Melgaço}

\section{Fieiral 2}

Localização administrativa: Lugar: n/a; Freguesia: Castro Laboreiro.

Contexto físico e ambiental: numa pequena plataforma do Alto dos Piornais, no topo do planalto de Castro Laboreiro, a $1169 \mathrm{~m}$ de altitude, nas imediações das Corgas do Fieiral, dos Piornais e do Vale das Antas, tributárias do rio Laboreiro. Há uma nascente contígua. Do local há domínio visual para prados próximos e para o vale do Castro Laboreiro.

Contexto arqueológico: o Fieiral 2 fica nas imediações das gravuras rupestres do Fieiral 1, distanciando-se destas cerca de 10 metros. Localiza-se, ainda, no seio da necrópole megalítica do planalto de Castro Laboreiro (Bettencourt e Rodrigues, 2013, p. 132). Caraterização do afloramento gravado: afloramento de granito, elevado do solo, de superfície superior irregular, com algumas diaclases significativas e áreas deprimidas (Bettencourt e Rodrigues, 2013, p. 132).

Descrição dos motivos gravados: Bettencourt e Rodrigues (2013) publicam uma ficha descritiva deste local tendo aí identificado, entre motivos da arte esquemática, como quadrados e retângulos segmentados e antropomorfos esquemáticos, inúmeras paletas de pá quadrangular com cabo delimitado por covinha. Identificaram, ainda, um machado plano de gume alargado, um círculo segmentado e podomorfos. Verificam que as paletas estão presentes na área mais interna da rocha, algumas sobrepondo-se a antropomorfos esquemáticos, como que alterando os signos anteriores. Observações recentes possibilitaram verificar que também existem na periferia este do afloramento, perto de um par de podomorfos (Figura 2). As paletas orientam-se para diversas orientações. Foram gravadas em baixo relevo e os cabos por picotagem seguida de abrasão (Bettencourt e Rodrigues, 2013). Cronologicamente, as autoras atribuem à Idade do Bronze, o machado plano de gume alargado e o círculo segmentado e, deste período ou posterior, um par de podomorfos. Sobre as paletas, afirmam serem motivos que se inserem na Idade do Ferro.

Bibliografia: Bettencourt e Rodrigues, 2013; dados inéditos. 


\subsubsection{Concelho de Ponte da Barca}

\section{Chã da Rapada 6-A}

Localização administrativa: Lugar: n/a; Freguesia: Britelo.

Contexto físico e ambiental: numa plataforma da vertente noroeste da serra Amarela, em local de portela natural entre as terras de vale e os patamares mais altos da serra. Deste sítio avistam-se as vertentes das serras do Soajo e Amarela e ainda o vale do Lima (Bettencourt, 2013, p. 162). O local é delimitado a norte e a sul por linhas de água que correm para o rio Lima.

Contexto arqueológico: no topo da serra encontra-se a necrópole megalítica do Britelo. A Chã da Rapada 6-A corresponde a um núcleo com inúmeros afloramentos gravados, maioritariamente com Arte Esquemática, embora ocorram motivos mais recentes.

Caraterização do afloramento gravado: afloramento granítico de grão médio a grosseiro, localizado na área central do núcleo de gravuras da Chã da Rapada, nas imediações das rochas 4 e 5 (Martins, 2006). Descrição dos motivos gravados: Martins (2006) estudou os afloramentos deste sítio, identificando uma paleta de pá quadrangular no que define como a rocha $n^{\circ} 6$, além de antropomorfos esquemáticos de mãos grandes, um antropomorfo esquemático de braços erguidos, quadrados simples e segmentados, que se encaixam na Arte Esquemática. Ocorrem, ainda cruciformes que parecem mais recentes (Fig. 1). Baptista (1986) considera duas fases de gravação para o conjunto da Chã da Rapada: uma primeira com motivos esquemáticos, circulares e idoliformes do Bronze Final e uma segunda, que atribui à época Medieval ou Moderna, onde insere os cruciformes. Seguindo esta proposta, Martins (2006) considera grande parte destes motivos à primeira fase de gravação, ou seja, à Proto-histórica, maioritariamente à Idade do Bronze, exceto a paleta que atribui à Idade do Ferro. Os cruciformes seriam também da Idade Média ou Moderna. Bettencourt (2013) sugere uma biografia mais complexa para este afloramento, defendendo que esteve simbolicamente ativo desde a Pré-história Recente até momentos históricos, sendo sujeito a adições ou alterações que mudaram o seu significado original, como é o que acontece na Idade do Ferro, através da paleta. Admite, ainda, que alguns antropomorfos possam ter sido gravados no
Neolítico Médio/Final, dado a sua organização com motivos reticulados inseríveis na arte Esquemática e associados a este período.

Bibliografia: Martins, 2006; Bettencourt, 2013.

\subsubsection{Concelho de Viana do Castelo}

\section{Laje da Churra}

Localização administrativa: Lugar: Paçô; Freguesia: Carreço.

Contexto físico e ambiental: no sopé da vertente oeste da Serra de Santa Luzia, sobranceiro ao ribeiro da Fonte Quente que desagua diretamente no oceano atlântico, a cerca de $44 \mathrm{~m}$ de altitude. É um afloramento com visibilidade restrita para o meio envolvente, pelo que talvez este lugar fosse intencionalmente "escondido" (Santos, 2014, p. 5).

Contexto arqueológico: da Laje da Churra há visibilidade para o monumento funerário da Cova da Moura, atribuível ao Bronze Final e para o Castro de Montedor (Santos, 2014, p. 5). A cerca de 2,7 km fica o povoado do Bronze Final de Santo António, em Afife.

Caraterização do afloramento gravado: afloramento de granito porfiróide de grão fino, ou médio a fino com aproximadamente $400 \mathrm{~m}^{2}$ (Santos, p. 5). É destacado do solo, com uma plataforma superior pequena a norte, de onde parte um desnível acentuado para oeste provocado por extração de pedra. Para este e sul, existem declives suaves. Após o primeiro declive, a este, há um grande patamar horizontalizado, de onde partem novos declives para nascente e sul. Verificam-se, também, declives a oeste e sudoeste (Santos, 2014, p. 45-47).

Descrição dos motivos gravados: Santos (2014) identifica 1170 motivos, entre eles círculos segmentados, zoomorfos, barquiformes, antropomorfos, armas e ferramentas, covinhas, raras espirais e algumas paletas variadas, segundo os critérios usados neste trabalho (Figura 3), como as de pá quadrangular, retangular, semicirculares, ovais, etc.

Distribuem-se nos painéis 2, 3, 5 e 11a, 11b e 11c.

As sobreposições, diferentes motivos e técnicas levou (Santos, 2014, p. 5) a considerar que a Laje da Churra foi gravada entre o Neolítico/Calcolítico e a Idade do Ferro, embora existam alguns elementos de períodos históricos, como cruzes.

Bibliografia: Santos, 2014. 


\subsection{Distrito de Vila Real}

\subsubsection{Concelho de Chaves}

Outeiro da Moeda 1, 2 e 3

Localização administrativa: Lugar: Quinta do Salgueirinho; Freguesia: Mairos.

Contexto físico e ambiental: o Outeiro da Moeda corresponde a um aglomerado de afloramentos graníticos, de entre 20 a $30 \mathrm{~m}$, dispostos no sentido norte-sul. É nessa área que se localizam as gravuras rupestres. A nascente deste local existe um curso de água.

Contexto arqueológico: a cerca de $500 \mathrm{~m}$ para sul fica o conjunto de gravuras do Outeiro do Tripe. Segundo Mário Reis Soares, no âmbito dos trabalhos de Relocalização, Identificação e Inspeção de Sítios pela extensão do IPA - Macedo de Cavaleiros, realizados em 2004, foram encontrados no Outeiro da Moeda, alguns indícios de vestígios arqueológicos, provavelmente pré-históricos.

Caraterização dos afloramentos gravados: segundo a descrição de Mário Reis (Portal do Arqueólogo, CNS 3619), as gravuras localizam-se na área do afloramento mais destacado, existente a norte do Outeiro da Moeda, onde há um pequeno abrigo definido por uma pala bem evidente.

Caraterização dos motivos gravados: o local é conhecido deste os anos 40 do séc. XX (Santos Júnior, 1940) mas a descrição mais detalhada pertence a Mário Reis (Portal do Arqueólogo, CNS 3619). Aqui ocorrem três afloramentos gravados apenas com paletas de pá retangular e cabo rematado por pequena covinha. Todas foram gravadas em baixo relevo. No afloramento com maior número de motivos, o Outeiro da Moeda 1, identificaram-se cerca de uma vintena de paletas gravadas numa pendente orientada para poente. Pelo lado exterior da pala do abrigo, e contíguo ao afloramento anterior, encontra-se o Outeiro da Moeda 2, de pequenas dimensões, com uma superfície aplanada e contorno trapezoidal. Aí foi gravada uma única paleta que se encontra muito erodida. O Outeiro da Moeda 3, fica no interior do abrigo, num bloco granítico irregular, de superfícies tendencialmente horizontais onde se gravaram três paletas de pequenas dimensões.

Bibliografia: Santos Júnior, 1940; Portal do arqueólogo, CNS 3619 .
Tripe 8

Localização administrativa: Lugar: n/a; Freguesia: Mairos.

Contexto físico e ambiental: no interior de um vasto "anfiteatro" natural, suavemente afunilado para sul e sudoeste (Baptista, 1984) a cerca de 770 $\mathrm{m}$ de altitude. Do local há visibilidade para o vale do Tâmega.

Caraterização dos afloramentos gravados: Trata-se de um bloco solto (Valdez, 2010) feito de granito de grão fino a médio (Baptista, 1984).

Caraterização dos motivos gravados: Pelo decalque de António Martinho Baptista e pela fotografia de Valdez (2010, p. 198), verifica-se que os motivos de Tripe 8 correspondem a uma paleta de pá retangular e cabo vertical atravessado por um traço perpendicular espessado junto ao cabo, um ou dois possíveis antropomorfos inseríveis na Arte Esquemática, e vários cruciformes (Figura 4).

Técnica de percussão é picotagem, na sua maioria, mas a paleta é em baixo relevo.

Bibliografia: Baptista, 1984; Valdez, 2010.

\section{Outeiro Machado 1}

Localização administrativa: Lugar: Boqueiro; Freguesia: Vale de Anta.

Contexto físico e ambiental: O Outeiro Machado I localiza-se num patamar da serra do Boqueiro a $436 \mathrm{~m}$ de altitude, com visibilidade para o vale do Tâmega.

Caraterização dos afloramentos gravados: Trata-se de uma afloramento muito destacado do solo, de forma alongada e de contorno sensivelmente ovalado, com uma superfície superior ligeiramente abaulada. Apesar de partido numa das extremidades, mede, ainda, cerca de $18 \mathrm{~m}$ de comprimento, por 6 $\mathrm{m}$ de largura e $3 \mathrm{~m}$ de altura.

Caraterização dos motivos gravados: O Outeiro Machado é referido na bibliografia arqueológica desde os inícios do séc. XX (Vasconcelos, 1917; Sampaio, 1928; Corrêa, 1929; Santos Júnior, 1940; Cardoso, 1942). Apesar de ter sido classificado como IIP - Imóvel de Interesse Público, pelo Decreto n.ำ

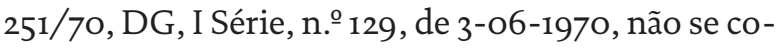
nhece nenhum trabalho monográfico, recente, sobre este local.

No seu topo Santos Júnior identificou mais de 500 motivos gravados, distribuídos pela superfície superior e início das pendentes, seguindo diversas 
orientações e normalmente sem articulação entre eles. Destacam-se quadrados segmentados, alguns deles cristianizados posteriormente, antropomorfos de diferentes configurações (em "fi" e em arco ultrapassado), figuras semicirculares, tradicionalmente conhecidas como "ferraduras" (algumas delas com covinha ou sulco no interior) e retângulos segmentados ou escaleriformes e um eventual idoliforme, inseríveis na Arte Esquemática. Ocorrem, ainda, dois possíveis machados encabados que estão na origem da designação do lugar, círculos segmentados, paletas de diversos tipos (de pás quadrangulares, circulares e semicirculares, entre outras, com distintos tipos de cabos), covinhas, covinhas associadas a sulcos curvos, inúmeros cruciformes de diferentes estilos (alguns deles representando cruzes latinas, outros podendo ser marcas de termo), entre outros motivos que só um estudo detalhado e com técnicas mais sofisticadas do que as usadas por Corrêa (1929) e Santos Júnior (1978) permitirá identificar. As paletas distribuem-se, essencialmente, pela periferia do afloramento e orientam-se para várias direções (Figura 5).

Bibliografia principal: Vasconcelos, 1917; Sampaio, 1928; Corrêa, 1929; Santos Júnior, 1940; Cardoso, 1942.

\subsubsection{Concelho de Mondim de Basto}

\section{Campelo 1}

Localização administrativa: Lugar: Campos; Freguesia: Mondim de Basto.

Contexto físico e ambiental: Campelo 1 localiza-se numa plataforma estreita da vertente oeste do Monte da Senhora da Graça ou Monte Farinha, rodeada a noroeste e a sudoeste por pequenos outeiros, a 420 $\mathrm{m}$ de altitude. Do local apenas há boa visibilidade para este. Nas imediações há uma nascente e uma linha de água que corre para a ribeira do Ramilo. $\mathrm{O}$ substrato rochoso é composto por granito de duas micas, de grão médio (Dinis, 2011).

Caraterização dos afloramentos gravados: de grandes dimensões, tem uma volumetria arredondada e a sua superfície é bastante irregular apresentando protuberâncias e fendas (Dinis, 2011).

Caraterização dos motivos gravados: Campelo 1 é subdivisível em 2 painéis de composições circulares (espirais e círculos concêntricos, com e sem covinha central) unidas por sulcos, inseríveis na Arte Atlântica (Dinis, 2011). Este autor identifica, ainda, sulcos bastante espessos, sobrepostas a algumas composições circulares ou rodeando-as, de onde saem inúmeras paletas, pelo que estas se localizam, essencialmente, na periferia dos motivos atlânticos. As paletas são de pá quadrangular, de pá retangular ou sub-retangular e de pá subcircular (Figura 6).

\section{Campelo 3}

Localização administrativa: Lugar: Campos; Freguesia: Mondim de Basto.

Contexto físico e ambiental: numa plataforma estreita da vertente oeste do Monte da Senhora da Graça ou Monte Farinha, rodeada a noroeste e sudoeste por pequenos outeiros, a $420 \mathrm{~m}$ de altitude. Do local apenas há boa visibilidade para este. Nas imediações há uma nascente e uma linha de água que corre para a ribeira do Ramilo.

Caraterização dos afloramentos gravados: O substrato rochoso é composto por granito de duas micas, de grão médio (Dinis, 2011). A sua superfície é sobrelevada, de contorno ovalado, porém o topo é aplanado (Dinis, 2011).

\section{Caraterização dos motivos gravados:}

Dinis (2011) identifica os motivos dividindo-os em 3 conjuntos, aos quais vamos entender como painéis. Identifica aí paletas, quadrados, covinhas e sulcos. As paletas neste afloramento são apenas de pá quadrangulares ou subcirculares.

Dinis (2011) observa que as paletas quadrangulares, diferentes em dimensão e disposição dos cabos, orientam-se para diferentes posições. As paletas circulares são mais uniformes entre elas, em termos morfológicos e das suas dimensões. As gravuras são todas feitas a baixo relevo (Figura 7).

\section{DISCUSSÃO DOS DADOS E INTERPRETAÇÕES}

As paletas são motivos muito raros no Noroeste de Portugal sendo conhecidas apenas em 11 afloramentos (Cabanas, Campelo 1 e 3, Chã da Rapada 6-A, Fieiral 2, Laje da Churra, Outeiro Machado 1, Outeiro da Moeda 1, 2 e 3 e Tripe 8) distribuídos por 8 núcleos. De uma forma geral localizam-se em áreas interiores e montanhosas, sendo a Laje da Churra o único sítio que se situa no litoral. Nota-se, igualmente, uma maior concentração de sítios com paletas na bacia do Tâmega, como Cabanas, Campelo 1 e 3, Outeiro Machado 1, Outeiro da Moeda 1, 2 e 3 e Tripe 8 (Figura 8). 
Em termos das características das superfícies gravadas as paletas localizam-se, maioritariamente em afloramentos sobrelevados (Campelos 1 e 3, Fieiral 2, Laje da Churra, Outeiro Machado 1, Outeiro da Moeda 1 e 2). A exceção encontra-se em Cabanas e na Chã da Rapada 6-A.

Encontram-se quer em contextos de Arte Atlântica Clássica, quer de Arte Esquemática de ar livre, embora também possam ocorrer em afloramentos onde são motivo único ou com motivos similares. No primeiro caso, encontra-se Campelo 1 e Laje da Churra, embora este último sítio tenha poucos motivos atlânticos clássicos. No segundo caso, maioritário, insere-se Cabanas (segundo Cardoso, 2015, p. 854), Chã da Rapada 6-A, Fieiral 2, Outeiro Machado 1 e Tripe 8. As paletas são motivo único no Outeiro da Moeda 1, 2 e 3 e associam-se a motivos similares, em Campelo 3.

No caso de Campelo 1, pela disposição dos motivos no conjunto e pela técnica (baixo relevo e sulcos mais alargados) que as paletas pertencem a um último momento de gravação do local, ou seja, sendo, portanto, posteriores aos motivos atlânticos. Segundo Dinis (2011) as composições circulares que correspondem ao momento mais antigo, têm sulcos menos profundos, sendo, muitas vezes, sobrepostos por motivos similares, mas com sulcos mais profundos e largos. Por último, gravaram-se vários sulcos sobrepostos aos círculos, que muitas vezes desembocam em paletas circulares ou retangulares. Neste caso, os sulcos onde se interligam as paletas parecem reorganizar a composição primitiva, como se a fechassem. No caso da Laje da Churra não há qualquer interação das paletas com os motivos atlânticos clássicos. Aqui elas parecem articular-se com outros motivos em baixo relevo, principalmente covinhas e covinhas com sulcos associados e um motivo que foi interpretado como um possível soliforme (painel 5). No caso dos sítios em que as paletas coincidem com motivos de arte esquemática, encontram-se, maioritariamente, na sua periferia ou distinguindo-se deles pela técnica de gravação (Cabanas, Chã da Rapada 6-A, Fieiral 2, Outeiro Machado 1, Tripe 8). De destacar o Fieiral 2 onde, pelo menos uma paleta, se sobrepõe a um antropomorfo esquemático, usando-o como cabo (Bettencourt e Rodrigues, 2013).

4. Afirme que os motivos da primeira fase cronológica de Cabanas corresponderem a um repertório que se encaixa na Arte Esquemática de ar livre.
Perante o conjunto de dados pode considerar-se que são posteriores cronologicamente às Artes Atlântica Clássica e Esquemática Antiga, que tem vindo a ser datadas do Neolítico e do Calcolítico (Alves, 2003, 2009; Cardoso, 2015; Bettencourt 2013, 2017a, $2017 \mathrm{~b}$, entre muitos outros). Assim, as paletas terão de ser posteriores, de acordo com muitas das propostas referidas na introdução deste texto, e pertencer a um outro grupo estilístico específico e emergente a partir da Idade do Bronze, tal como tem vindo a defender Bettencourt (2017a, 2017b, 2019).

Se tivermos em conta o número de afloramentos de Arte Atlântica Clássica conhecidos na fachada mais ocidental do Noroeste de Portugal, da ordem das muitas centenas (Alves, 2003; Cardoso, 2015; Bettencourt, Abad-Vidal, Rodrigues, 2017; Alves e Reis, 2017; Sampaio e Bettencourt, 2017; Bettencourt e Santos-Estévez, 2018) ou os de Arte Esquemática de ar livre, que se distribui, essencialmente, nas áreas mais interiores do Norte de Portugal (Baptista, 1983-1984; Abreu, 2012; Cardoso, 2015; Gomes, 2014) os locais com paletas parecem obedecer a outra ordem ideológica que privilegia, apenas, determinados lugares. De salientar que estes motivos também parecem raros na Galiza (Santos-Estévez, 2007, entre muitos outros).

Na conceção ampla de paleta, ou seja, de objetos com pá e cabo, distinguimos uma grande variedade que se podem subdividir em 6 grandes grupos consoante a forma da pá. Estabeleceram-se, também subgrupos, no contexto de cada grupo, consoante as orientações dos cabos face às pás (Tabela 1).

O grupo 1 caracteriza-se por pás quadrangulares, de diferentes dimensões, com cabos verticais ( $(\mathrm{A}$ ) ou curvos (1B). É de salientar que as terminações dos cabos destas paletas podem apresentar grande diversidade (Figura 9). Estes podem ser aguçados, circulares (fechados ou abertos), retangulares e trapezoidais. Aparecem em Campelo 1, Campelo 3, Chã da Rapada 6-A, Fieiral 2, Outeiro da Moeda 1, 2 e 3 e Outeiro Machado 1, sendo o grupo com maior representatividade. O grupo 2 é definido por pás retangulares ou sub-retangulares, dispostas na vertical, e cabos verticais $(2 \mathrm{~A})$ ou curvos $(2 \mathrm{~B})$. Constitui um grupo mais heterogéneo do que o anterior. Ocorrem em Cabanas, Campelo 1, Laje da Churra e Tripe 8. O grupo 3 caracteriza-se por pás circulares ou subcirculares e cabos verticais $(3 \mathrm{~A})$ ou curvos $\left({ }_{3} \mathrm{~B}\right)$. Ocorrem em Campelo 1, Campelo 3, Laje da Churra e Outeiro Machado 1. O grupo 4 define-se por paletas de 
pá semicircular, apenas presentes na Laje da Churra e Outeiro Machado 1. As identificadas tem apenas o cabo vertical. Trata-se de um grupo minoritário. O grupo 6 diz respeito a paletas de pá oval. É conhecida apenas uma na Laje da Churra. Finalmente, o grupo 6, de pá trapezoidal e cabo vertical com apenas um exemplar reconhecido, em Cabanas.

Se tivermos em conta a localização geográfica das paletas, à ampla escala de análise, as do grupo 1 , de pás quadrangulares, distribuem-se, totalmente, em áreas de altitude, entre 300 e 1169. Estas ocorrem apenas em Campelo 1 e 3 na Chã da Rapada 6-A, no Fieiral 2, em Outeiro da Moeda 1, 2 e 3 e no Outeiro Machado 1. As paletas do grupo 2, de pá retangular ou sub-retangular, também estão presentes essencialmente no interior, com exceção da Laje da Churra, localizada nas imediações da plataforma litoral. O mesmo se poderá dizer das paletas do grupo 3 e 4. A paleta do grupo 5 apenas ocorre no litoral.

Devido aos paralelos das paletas quadrangulares e retangulares com as de Valcamónica, em Itália, e das de pá circular, com os espelhos representados nas estelas do Sudoeste Ibérico, a introdução das paletas dos grupos 1, 2 e 3, no Noroeste de Portugal parece ser um fenómeno de influência mediterrânica que poderá ter sido introduzido na Idade do Bronze Final, no âmbito do intercâmbio suprarregional.

É provável que a estes grupos morfológicos correspondam artefactos distintos com funções distintas ou mesmo com discrepâncias cronológicas, mas esse tipo de análises efetuar-se-ão futuramente no decorrer de novos trabalhos sobre o assunto.

\section{BIBLIOGRAFIA}

ABREU, Maria Emília (2012) - Rock-Art in Portugal: History, Methodology and Traditions, Vila Real: Universidade de Trás-os-Montes e Alto Douro (Tese de Doutoramento).

ALVES, Lara (2003) - The Movement of Signs: Post-Glacial Rock Art in Northwestern Iberia. Reading: University of Reading (Tese de Doutoramento).

ALVES, Lara (2009) - O sentido dos signos. Reflexões e perspectivas para o estudo da arte rupestre do pós-glaciar no norte de Portugal In BALBÍN BEHRMANN, Rodrigo de, ed. - Arte prehistórico al aire libre en el sur de Europa, pp. 381-414.

ALVES, Lara; REIS, Mário (2017) - As gravuras rupestres do Monte Faro (Valença, Viana do Castelo) - um exemplo maior da Arte Atlântica peninsular. Portugália. Porto. Vol. 38, pp. 49-86.
BATISTA, António (1984) - Arte rupestre no norte de Portugal: uma perspetiva. Portugália. Vol. IV/V, pp. 71-86.

BETTENCOURT, Ana M. S. (2013) - A Pré-história do Noroeste Português. Braga/Tomar: Centro Europeu de Investigação da Pré-História do Alto Ribatejo.

BETTENCOURT, Ana M. S. (2017b) - Pos-Palaeolithic rock art of north-western Portugal: an approach, In BETTENCOURT, Ana; SANTOS-ESTÉVEZ, Manuel; SAMPAIO, Hugo; CARDOSO, Daniela, eds. - Recorded Places, Experienced Places: The Holocene rock art of the Iberian Atlantic northwest, pp. 123-150.

BETTENCOURT, Ana M. S. (2017a) - Gravuras Rupestres do Noroeste português para além das Artes Atlântica e Esquemática In ARNAUD, José M.; MARTINS, Andrea (eds.), Arqueologia em Portugal - 2017. Estado da Questão, Lisboa: AAP, pp. 1053-1067.

BETTENCOURT, Ana M. S. (2019) - Artes rupestres do Alto Minho. In CAMPELO, Álvaro, ed. - Património Artístico e Cultural do Alto Minho. Uma Viagem no Tempo. Viana do Castelo: Comunidade Intermunicipal do Alto Minho.

BETTENCOURT, Ana; RODRIGUES, Alda (2013) - “As gravuras rupestres do Fieiral, Castro Laboreiro, Melgaço" In BETTENCOURT, Ana. The Prehistory of the Northwestern Portugal, Territórios da Pré-história em Portugal, vol. 2, Braga/Tomar: CEIPHAR/CITCEM (E. Bilingue), 132-138.

CARDOSO, Daniela (2015) - Arte Atlântica do Monte de S. Romão (Guimarães) no Contexto da Arte Rupestre Pós-Paleolítica da Bacia do Ave-Noroeste Português. Vila Real: Universidade de Trás-os-Monte e Alto Douro (Tese de doutoramento).

CORRÊA, António (1929) - L’art rupestre en Traz os Montes (Portugal). Revue Archéologuique, 29: 121-136.

COSTAS GOBERNA, Fernando; NOVOA ALVARÉZ, Pablo (1993) - Los grabados rupestres de Galicia. Coruña: $\mathrm{Mu-}$ seu Arqueológico e Histórico, A Coruña.

DINIS, António P. (2011) - O santuário rupestre de Campelo, Mondim de Basto (Norte de Portugal). Oppidum, 5, pp. 11-26.

FERRI, Silvio (1975) - Il significato delle palette nell'arte rupestre della Valcamonica, in Les Religions de la Préhistoire, Valcamonica Symposium '72, 1975, pp. 263-269.

FOSSATI, Angelo (2007) - Figures and Male Sites in the Rock Art of Valcamonica, Italy in XXII Valcamonica Symposium 2007, Itália, pp. 131-144.

GOMES, Nuno (2014) - Estudo do Sítio com Gravuras Rupestres de Lamelas (S. Salvador) - Ribeira de Pena). Porto: Universidade do Porto (Dissertação de mestrado).

MARTINS, Andrea (2006) - Gravuras rupestres do Noroeste Peninsular: a Chã da Rapada, Revista Portuguesa de Arqueologia 9:1, pp. 47-70. 
PEÑA SANTOS, António; VASQUEZ VARELA, José (1979)

- Grabados rupestres prehistóricos al aire libre en Galicia, Cuadernos del Seminario de Estudios Cerámicos de Sargadelos 3o, Sada, La Coruña.

SAMPAIO, \& GARCIA DIEZ (200o) - A arte rupestre do Planalto da Lameira, Celorico de Basto e Fafe. Revista de Guimarães, 110, 189-207.

SANTOS, Ana F. (2014) - A Laje da Churra (Carreço, Viana do Castelo). Estudo Monográfico de um Lugar Gravado, Braga: Universidade do Minho (Dissertação de Mestrado).

SANTOS-ESTÉVEZ, Manuel (2007) - Petroglifos y Paisaje Social en la Prehistoria Reciente del Noroeste de la Península Ibérica In Instituto de Estudios Gallegos Padre Sarmiento, Traballos de Arqueoloxía e Patrimonio (TAPA), TAPA 38, Santiago de Compostela, pp. 13-215.
SANTOS JÚNIOR, Joaquim (1940) - Arte rupestre. I Congresso do Mundo Português. Memórias e Comunicações Apresentadas ao Congresso da Pré e Proto-História de Portugal. Lisboa: Bertrand e Comissão Executiva dos Centenários. Secção de Congressos. Vol.1, pp. 327-376.

SANTOS JÚNIOR, Joaquim (1978) - As gravuras rupestres do Outeiro Machado (Vale d'Anta-Chaves). Trabalhos de Antropologia e Etnologia, 23, 2-3, pp. 207-234

VALDEZ, Joana (2010) - Gravura na Arte Esquemática do Noroeste Peninsular. O caso do Monte de Góios (Lanhelas, Caminha). Porto: Faculdade de Letras da Universidade do Porto (Dissertação de Mestrado).
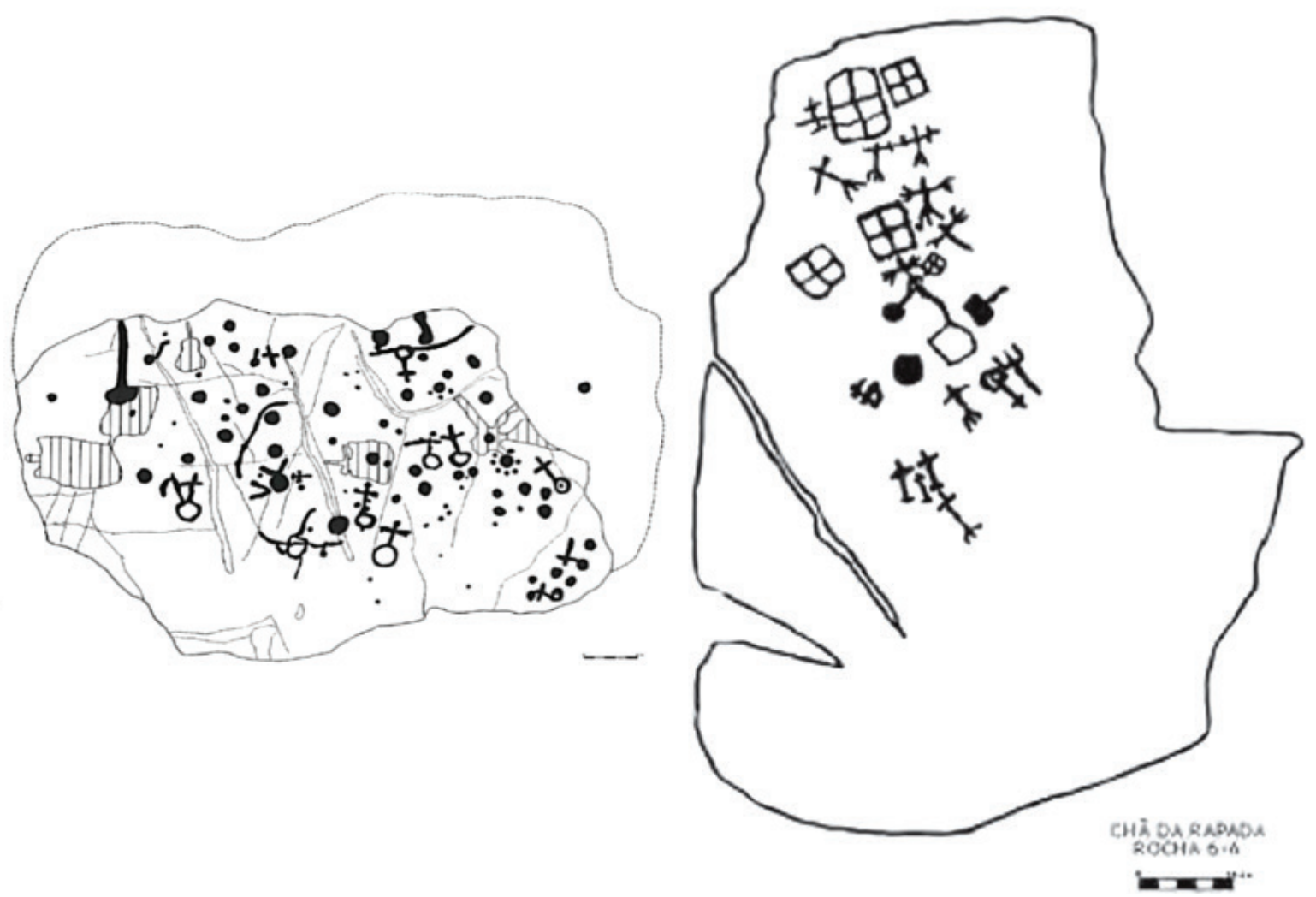

Figura 1 - À esquerda: decalque de Cabanas (seg. Sampaio e Garcia Diez, 200o). Á direita: decalque da Chã da Rapada 6-A (seg. Martins, 2006). 

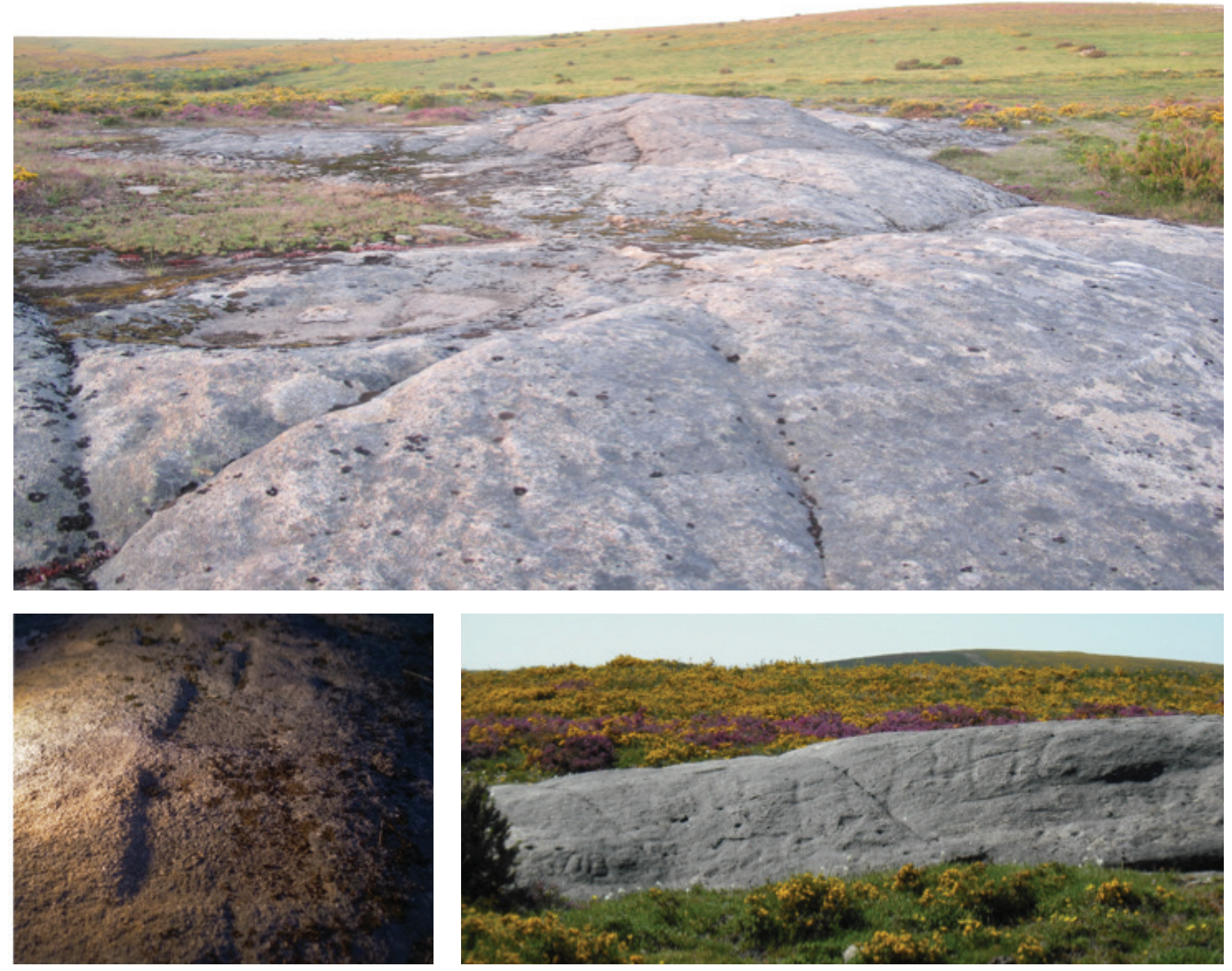

Figura 2-Em cima: aspeto geral do Fieiral 2. Em baixo, à esquerda: paletas da parte interna do afloramento. Em baixo, à direita: grupo de paletas na base da pendente este (a meio). 


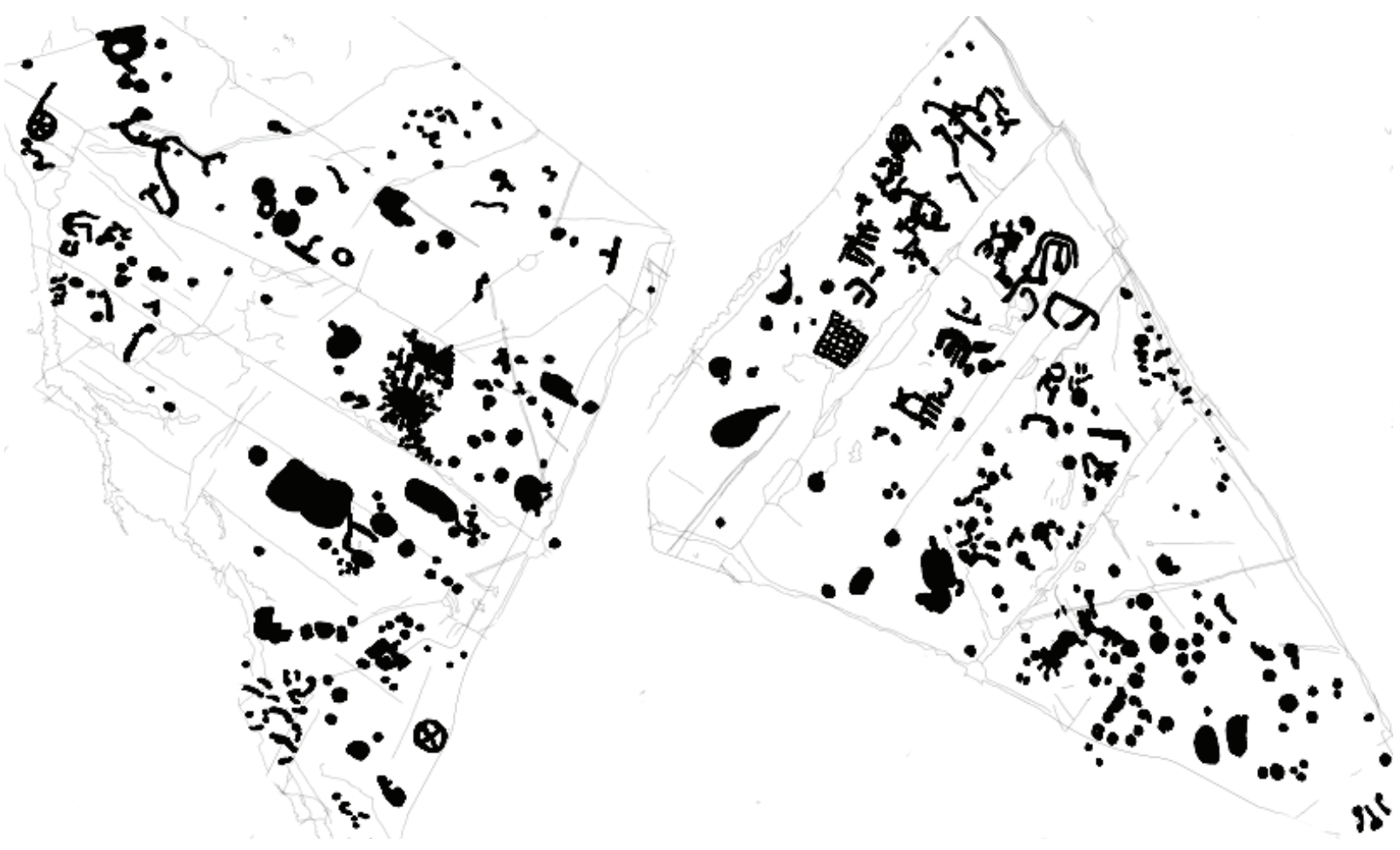

Figura 3 - Decalque dos painéis 5 e 11 A da Laje da Churra onde se podem observar paletas de vários tipos (seg. Santos, 2014, p. 55,62 , adaptado).
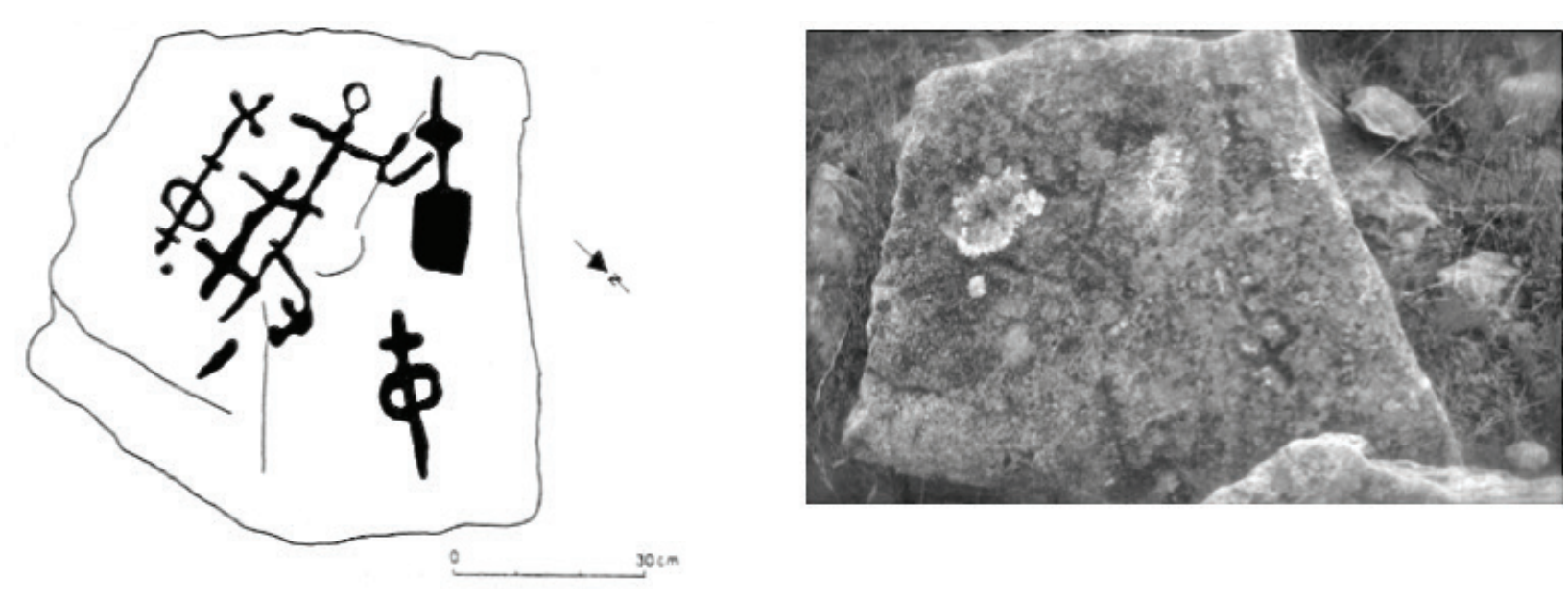

Figura 4 - Decalque realizado por António Martinho Baptista (seg. Jorge e Jorge, 1991) e fotografia deste bloco gravado (seg. Valdez, 2010, p. 198). 


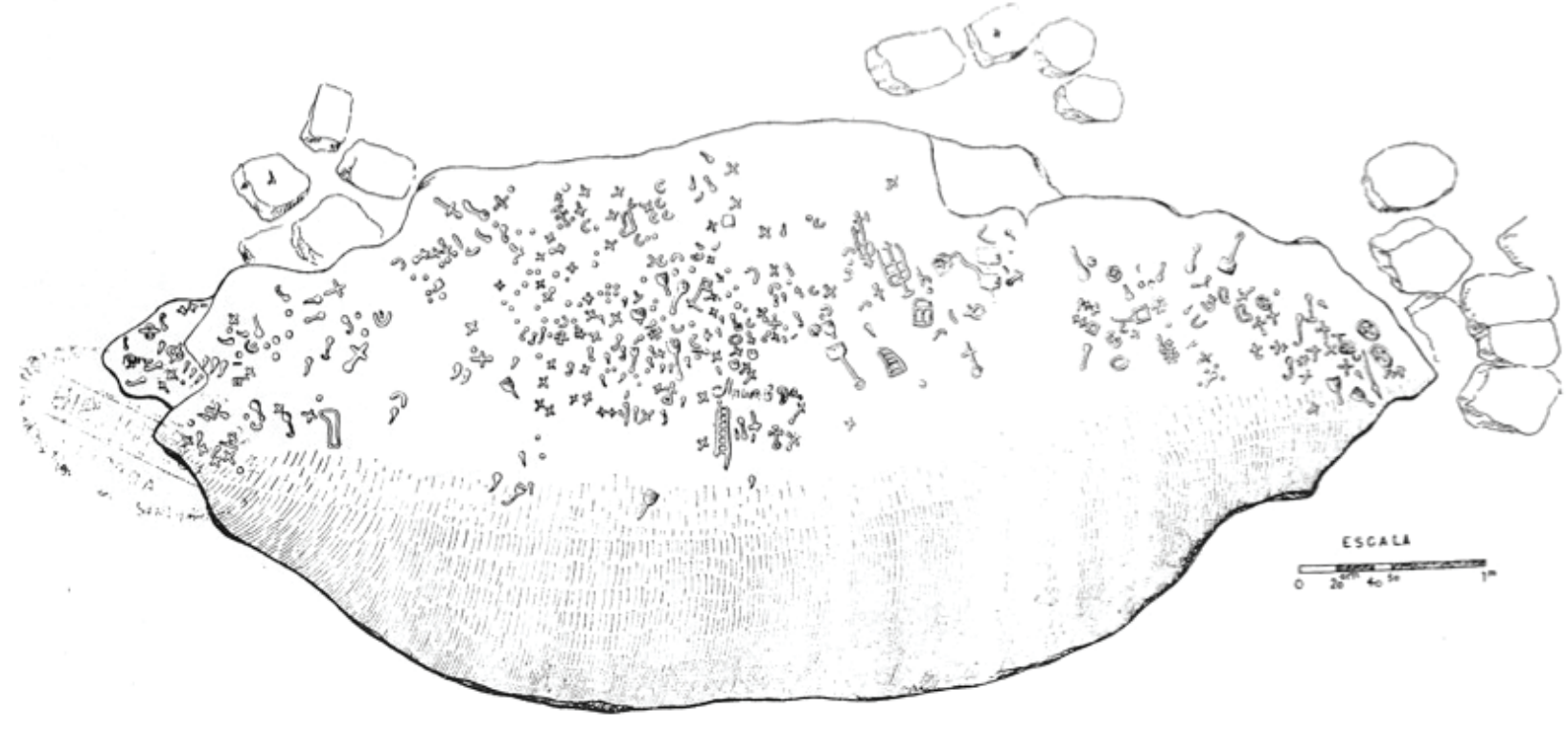

Figura 5 - Desenho de Outeiro Machado 1 (seg. Mendes Corrêa, 1929).

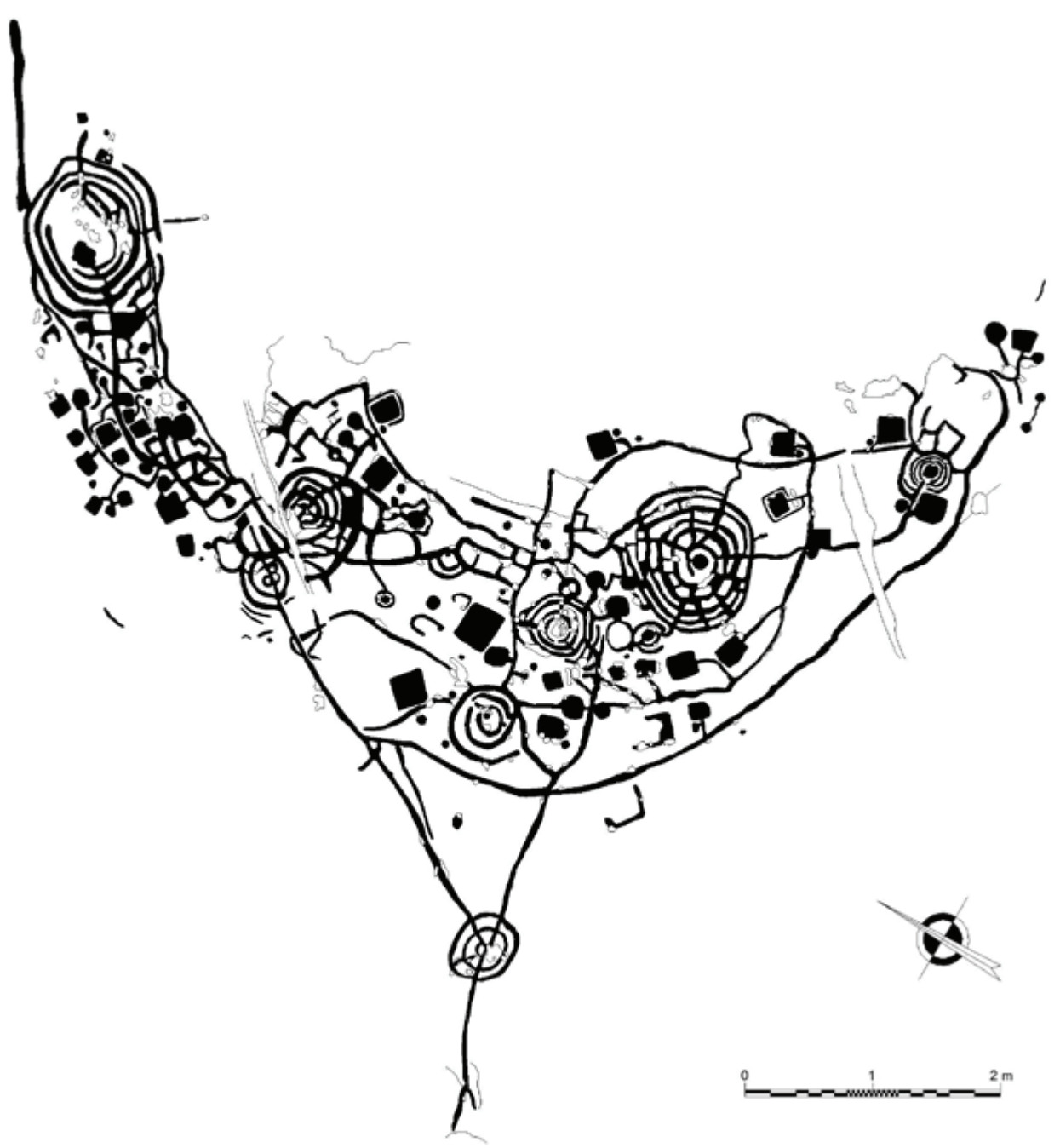

Figura 6 - Decalque de Campelo 1 (seg. Dinis, 2011). 

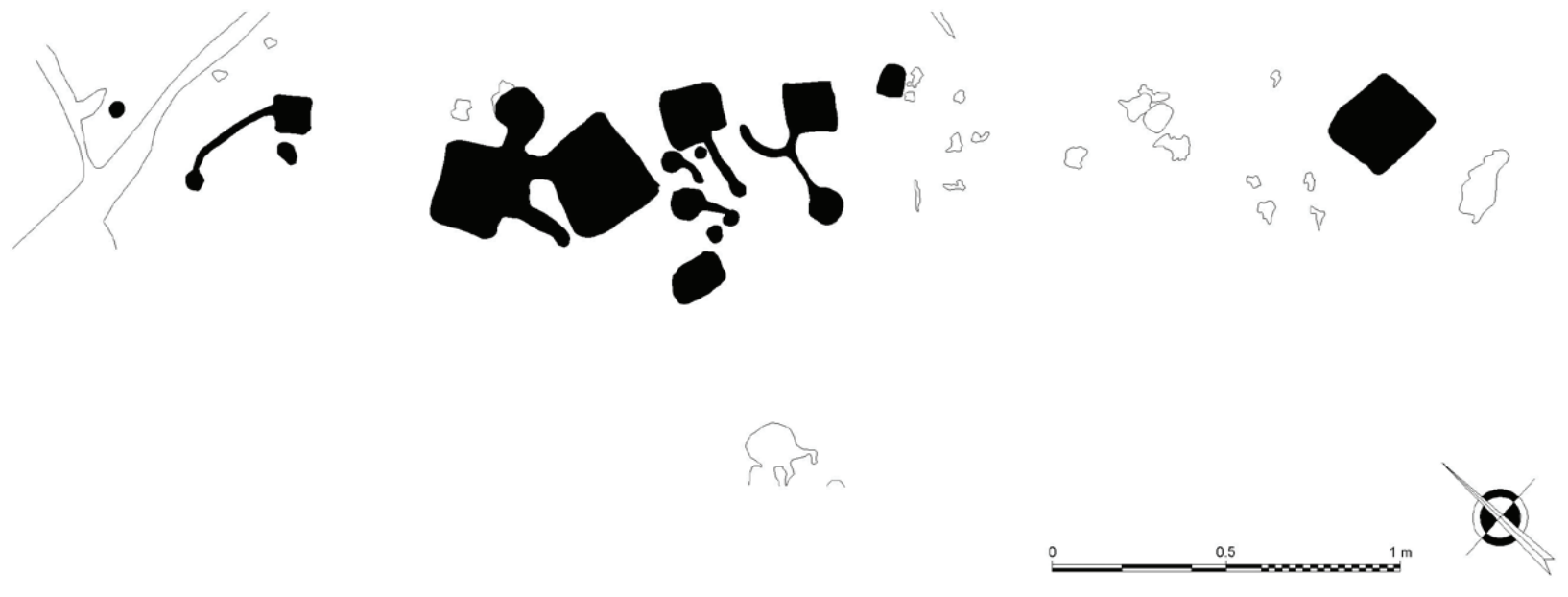

Figura 7 - Decalque de Campelo 3 (seg. Dinis, 2011).

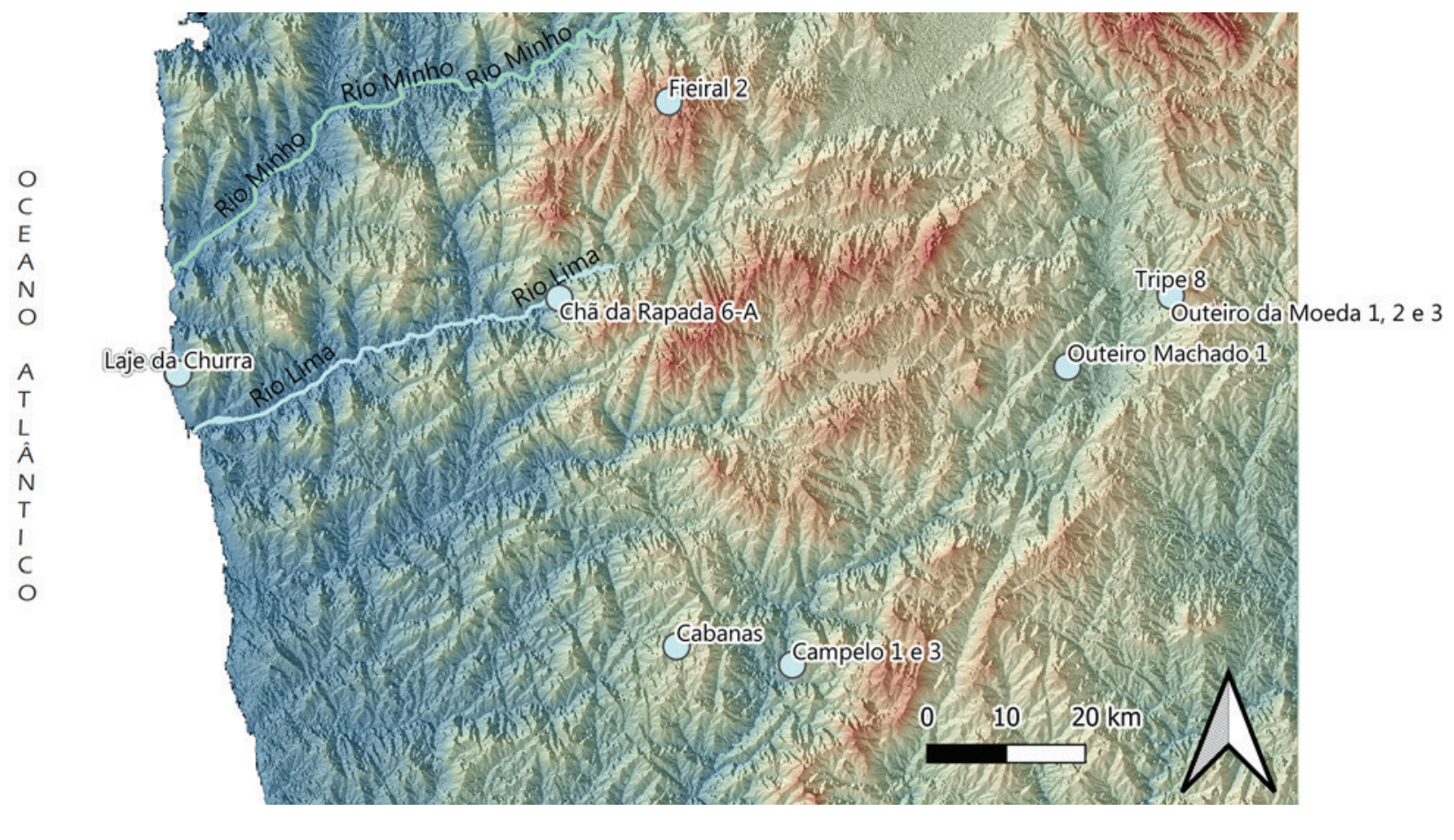

Figura 8 - Localização dos núcleos de arte rupestre com paletas estudados no texto, no Noroeste de Portugal. 


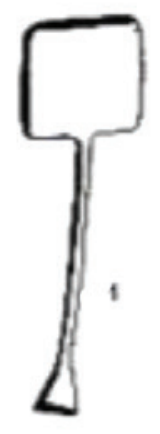

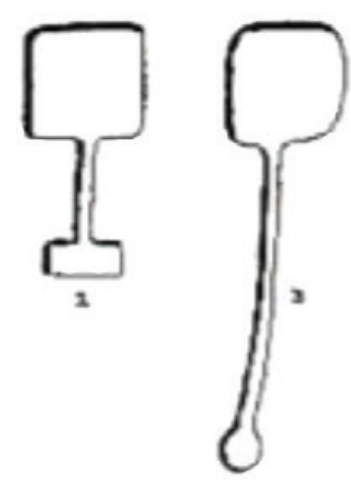

A

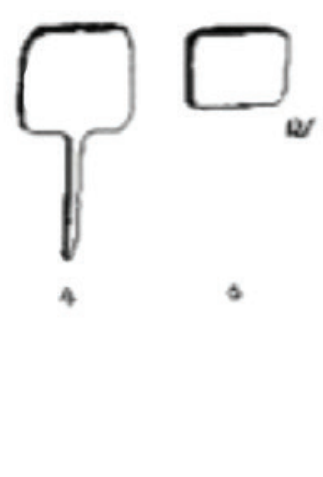

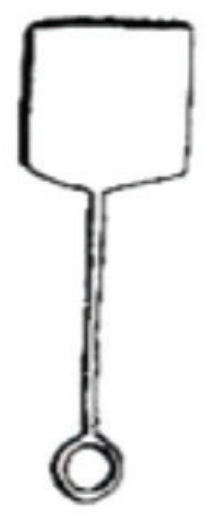

B

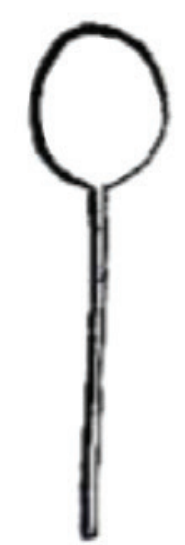

2.

Figura 9 - Diferentes tipos de paletas dos grupos 1 e 3 de Outeiro Machado 1 (seg. Corrêa 1929, p. 129). Note-se a diversidade da terminação dos cabos.

\begin{tabular}{|c|c|c|}
\hline \multirow{2}{*}{ Grupo 1} & \multicolumn{2}{|l|}{ Pá quadrangular } \\
\hline & A - Cabo vertical & B - Cabo curvo \\
\hline \multirow{2}{*}{ Grupo 2} & \multicolumn{2}{|c|}{ Pá retangular ou sub-retangular } \\
\hline & A - Cabo vertical & B - Cabo curvo \\
\hline \multirow{3}{*}{ Grupo 3} & \multicolumn{2}{|c|}{ Pá circular ou subcircular } \\
\hline & A - Cabo vertical & B - Cabo curvo \\
\hline & \multicolumn{2}{|l|}{ Pá semicircular } \\
\hline Grupo 4 & & \\
\hline \multirow[b]{2}{*}{ Grupo 5} & \multicolumn{2}{|l|}{ Pá oval } \\
\hline & & \\
\hline \multirow[b]{2}{*}{ Grupo 6} & \multicolumn{2}{|l|}{ Pá trapezoidal } \\
\hline & & \\
\hline
\end{tabular}

Tabela 1 - Quadro morfológico das paletas. 



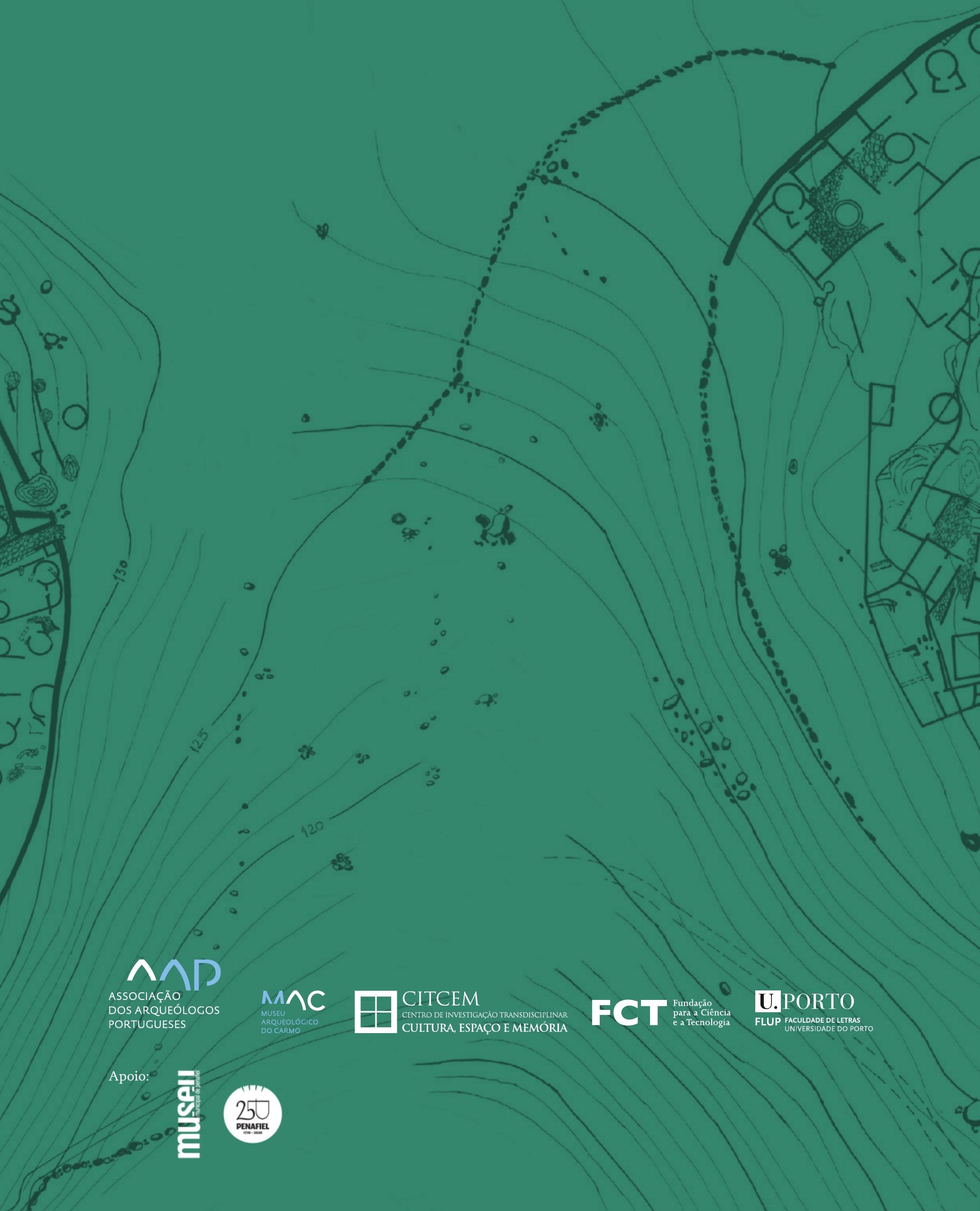

